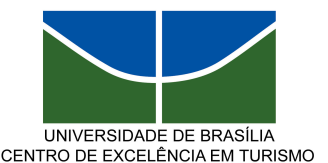

UNIVERSIDADE DE BRASÍLIA

Centro de Excelência em Turismo

Pós-graduação Lato Sensu

Curso de Especialização em Turismo e Desenvolvimento Sustentável

\title{
PERSPECTIVAS TURÍSTICAS DA BARRA DO RIBEIRA
}

Fabianne Yoko Ykemoto

Esp. Rogério Ferreira de Souza Dias

Brasília - 2007 


\title{
PERSPECTIVAS TURÍSTICAS DA BARRA DO RIBEIRA
}

\author{
Fabianne Yoko Ykemoto
}

Esp. Rogério Ferreira de Souza Dias

Monografia apresentada ao Centro de Excelência em Turismo - CET, da Universidade de Brasília - UnB, como requisito parcial à obtenção do grau de Especialista em Turismo e Desenvolvimento Sustentável.

Brasília - 2007 


\section{UNIVERSIDADE DE BRASÍLIA}

Centro de Excelência em Turismo

Pós-graduação Lato Sensu

Curso de Especialização em Turismo e Desenvolvimento Sustentável

\section{Fabianne Yoko Ykemoto}

Aprovado por:

Esp. Rogério Ferreira de Souza Dias (orientador)

Dra. Dóris Sayago

Msc. Elisângela Aparecida Machado Silva

Brasília, 25 de junho de 2007. 
Ykemoto, Fabianne Y.

Perspectivas Turísticas da Barra do Ribeira. Fabianne Ykemoto. - Brasília, 2007.VII, 52 p.

Monografia (especialização) - Universidade de Brasília, Centro de Excelência em Turismo, 2007.

Orientador: Rogério Dias.

1. Turismo. 2.Perspectivas Turísticas da Barra do Ribeira. I. Título. 


\section{AGRADECIMENTOS}

Aos meus familiares pelo apoio, pelo incentivo e pela motivação nessa nova fase de minha vida e que acreditaram em mim.

Agradeço a todos que me ajudaram e participaram da minha vida durante a minha estada em Brasília, especialmente àqueles que além de amigos, foram a minha segunda família, Gabriela, Mita, Eduardo, Kiara, Leonardo, Franscisco e Carlos Alberto. À Selma, Veridiana, Isabel e Ricardo que me incentivaram e proporcionaram um ótimo convívio em meu ambiente de trabalho.

Aos colegas de curso pela nova amizade, e que além da companhia desfrutada ao longo do curso, proporcionaram discussões interessantes sobre os novos conhecimentos adquiridos.

Aos professores, que me apoiaram durante o curso, principalmente ao meu orientador Prof. Rogério, as Prof ${ }^{\mathrm{as}}$ Iara, Sonia e Dóris e ao Prof ${ }^{\mathrm{s}}$ Sérgio, e todos os outros que contribuíram para a minha formação acadêmica.

Agradecimentos especiais ao Milton e a Marli que sempre me hospedaram em sua casa na Barra do Ribeira, permitindo que eu tomasse conhecimento sobre o local. A todos que se dispuseram a me atender e me passar informações sobre a Barra do Ribeira, enriquecendo ainda mais meu trabalho: Tapico (AMAI), Dauro Prado (IBAMA/AJJ), Tiago (IBAMA), José Carlos (Pousada Ecológica), Dona Marta, Cybele (Eco Juréia) e Luciano (Ing- Ong) e aos novos amigos Eric, Flávia e Toninho.

Agradeço também a minha prima Giuliana que me acompanhou durante as viagens para a Barra do Ribeira, além de me apoiar e ajudar na execução deste trabalho e também a minha amiga Renata, pela companhia em outra visita ao local, e por suas sugestões e críticas. 


\section{RESUMO}

O presente trabalho trata da questão do turismo como instrumento para o desenvolvimento da Barra do Ribeira no Município de Iguape, São Paulo e tem como objetivo principal apontar sugestões para a melhoria do turismo no local. Para melhor alcançar o objetivo, a autora analisa os projetos de turismo e desenvolvimento sustentável que foram realizados na região. O trabalho traz um breve histórico sobre a Barra do Ribeira, abordando sobre os aspectos ambientais, como a criação das unidades de conservação em que o bairro está inserido; assim como os aspectos sociais do local, destacando a atuação e a participação da comunidade nos projetos realizados. Foram contempladas questões como turismo no entorno de unidades de conservação, envolvimento de comunidades tradicionais e preservação do patrimônio ambiental e cultural.

Palavras-chave: turismo; desenvolvimento sustentável, participação da comunidade local. 


\begin{abstract}
This article treat the matter of tourism as an instrument of development of Barra do Ribeira in Iguape, São Paulo, and as principal aims to analyze the present situation of touristical projects and the sustanaible development. To discuss and to emphasize the justification of the local choice, this paper brings a historical brief about the occupation of Barra do Ribeira, approaching around the ambiental context entered. The text presents the theorics arguments based in a tourist concepts and sustainable and also matters as the tourism in the spill of the conservation of areas, the involvement of traditional populations, preservation of the heritage and governamental orientations.
\end{abstract}

Keywords: Tourism, sustainable development, local participation. 


\section{LISTA DE SIGLAS}

AEJ - Associação Eco Juréia

AJJ - Associação dos Jovens da Juréia

AMAl - Associação dos Monitores Ambientais de Iguape

APA- CIP - Área de Proteção Ambiental Cananéia - Iguape - Peruíbe

ARTESP - Agência Reguladora de Serviços Públicos Delegados de Transporte do

Estado de São Paulo

CEAM- Coordenadoria de Educação Ambiental

CEPAM - Centro de Estudos de Administração Pública

CETESB - Companhia de Tecnologia de Saneamento Ambiental

CODIVAR - Consórcio que congrega e representa todos os 24 municípios do Vale

CONDEPHAAT - Conselho de Defesa do Patrimônio Histórico, Artístico e Turístico

DER - Departamento de Estradas e Rodagens

DERSA - Desenvolvimento Rodoviário S. A

EEJI - Estação Ecológica Juréia Itatins

EMBRATUR - Instituto Brasileiro de Turismo

Esalq - Escola Superior de Agricultura Luiz de Queiroz

FAT - Fundo de Amparo ao Trabalhador

IBAMA - Instituto Brasileiro do Meio Ambiente e dos Recursos Naturais Renováveis IEB - Instituto de Ecoturismo do Brasil

NUCLEBRÁS - Empresas Brasileiras Nucleares

NUPAUB - Núcleo de Apoio a Pesquisa sobre Populações Humanas e Áreas Úmidas

OMT - Organização Mundial do Turismo

OSCIP - Organização da Sociedade Civil de Interesse Público

PED - Projetos de Execução Descentralizada

PEL - Pólo Ecoturístico do Lagamar

PNUMA - Programa das Nações Unidas para o Meio Ambiente

RDS - Reserva de Desenvolvimento Sustentável

SENAC/SP - Serviço Nacional de Aprendizagem Comercial 
SMA - Secretaria do Meio Ambiente

SUDELPA - Superintendência de Desenvolvimento do Litoral Paulista USP - Universidade de São Paulo

UNICAMP - Universidade de Campinas 


\section{SUMÁRIO}

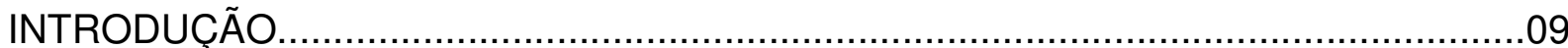

CAPÍTULO 1- Abordagem sócio- ambiental da Barra do

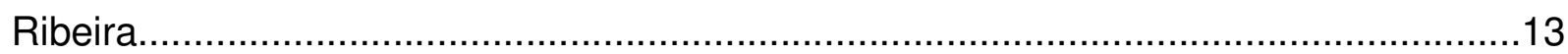

1.1 Turismo e Desenvolvimento sustentável: preservando o patrimônio e envolvendo a população local através de políticas públicas .................................18

CAPÍTULO 2 Projetos de Turismo e Desenvolvimento Sustentável na Barra do Ribeira 26

CAPÍTULO 3 Barra do Ribeira e seu potencial

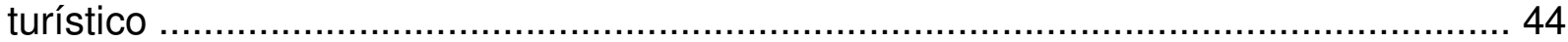

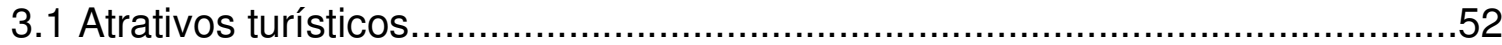

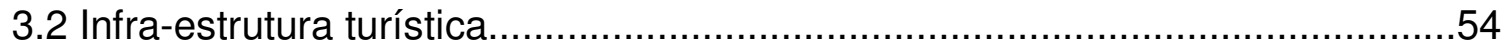

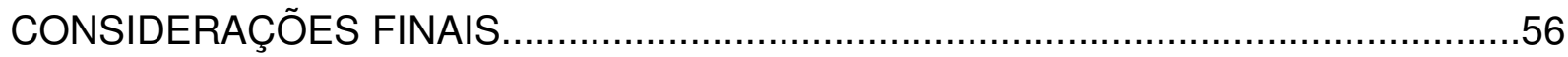

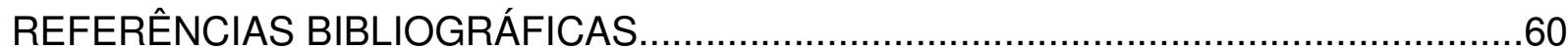




\section{Introdução}

A Barra do Ribeira, situada a $18 \mathrm{~km}$ da sede do município de Iguape, no litoral sul de São Paulo é uma das portas de entrada para a Estação Ecológica Juréia-Itatins, onde também está inserida a Área de Proteção Ambiental Federal Cananéia- IguapePeruíbe, sendo uma região de paisagem exuberante com uma expressiva relevância no contexto de conservação da Mata Atlântica. Entretanto, a Barra do Ribeira é uma das localidades mais pobres do Estado de São Paulo, com um dos menores Índices de Desenvolvimento Humano $(\mathrm{IDH})$ de $0,76^{1}$, sendo que o difícil acesso à região agrava ainda mais a falta de infra-estrutura básica e o saneamento básico. Somando-se a isso, verifica-se um certo descaso por parte da administração pública local (Prefeitura Municipal de Iguape), no que diz respeito à melhoria de vida da população, apesar dos esforços das Associações formadas pela comunidade da Barra do Ribeira. Considerando-se tais fatores e que o local possui um grande potencial turístico, com atrativos naturais quase intocados, trilhas, a cultura caiçara e um ambiente propício para a prática de esportes, verifica-se um descompasso entre a conservação ambiental e o desenvolvimento.

A criação da Estação Ecológica Juréia- Itatins em 1987 foi uma importante conquista dos ambientalistas em conservar a Mata Atlântica, porém tida como uma ameaça para a população tradicional residente dentro da Estação, pois a criação da Estação não ofereceu uma alternativa para o sustento da população, que ficou proibida de exercer as atividades rotineiras devido às implicações legislativas de uma Estação Ecológica. Em conseqüência disso, a população da Juréia se deslocou para localidades próximas, inclusive a Barra do Ribeira, e para os que restaram dentro da estação se instaurou uma luta para a sobrevivência. A população que se fixou na Barra do Ribeira encontrou no desenvolvimento da atividade pesqueira e no turismo, as alternativas para a obtenção de renda. No entanto o turismo foi sendo exercido de forma lenta e aleatória, visto que inicialmente apenas os turistas que tinham casa na região passavam

\footnotetext{
${ }^{1}$ Associação Paulista de Municípios. Disponível em: http://www.apaulista.org.br. Acesso em 22 de março de 2007
} 
temporadas na Barra do Ribeira. Apesar de alguns poucos condicionantes serem favoráveis para o exercício da atividade turística, não foi realizado um planejamento consistente, resultando em queixas apresentadas por moradores ao administrador da Barra do Ribeira referentes às condições precárias do local, como infra-estrutura, saneamento, saúde e coleta de lixo.

Recentemente em 12 de dezembro de 2006, foi aprovada a Lei nำ12406, que transforma a parte ocupada da Juréia-Itatins em Reservas de Desenvolvimento Sustentável (RDS), criando as duas primeiras RDS do Estado de São Paulo, além de criar o Parque Estadual do Prelado, próximo a Barra do Ribeira, que possibilita a execução da atividade turística, o que pode proporcionar benefícios para a população local. Tendo em vista a alteração de parte da Estação Ecológica em RDS e Parque Estadual, o planejamento de um turismo sustentável torna-se essencial para o desenvolvimento da região, principalmente para oferecer à população condições de vida dignas aliadas à conservação e a valorização do Patrimônio Natural e Cultural da Barra do Ribeira.

Verifica-se a urgência de se elaborar um planejamento turístico para a Barra do Ribeira, de forma a capacitar a população para atender o aumento da demanda turística que ocorrerá com a criação de um Parque Estadual no local; oferecer infra-estrutura turística e controlar o acesso à Barra do Ribeira. Dessa forma, a questão identificada na Barra do Ribeira: é de que forma o turismo pode contribuir para o desenvolvimento sustentável e a conservação do patrimônio natural e cultural da Barra do Ribeira?

Constatando-se que não foi realizado um planejamento turístico na região da Barra do Ribeira, o objetivo deste trabalho é apresentar sugestões para a melhoria do turismo no local, de modo a atender aos princípios de sustentabilidade e a inserir a população local como prioritária para ser beneficiária da atividade turística. Os objetivos específicos deste trabalho são: apresentar um esboço histórico da região, verificar as ações realizadas no âmbito do turismo e de desenvolvimento sustentável; identificar e analisar as principais carências e problemas existentes; caracterizar os atrativos e infraestrutura turísticas do local e sugerir ações para a melhoria da presente situação.

Como referencial teórico e bibliográfico foram utilizados conceitos a cerca do turismo e sua sustentabilidade, principalmente em áreas de entorno de Unidades de 
Conservação, assim como a importância do envolvimento e da participação da comunidade local no exercício da atividade turística. Também foram abordados aspectos relevantes da área, como a sua história, geografia e sua inserção no contexto de conservação do meio ambiente.

Tendo em vista a situação atual do turismo na Barra do Ribeira, o turismo sustentável se apresenta como uma solução viável para a geração de renda e melhoria na infra-estrutura básica, como acesso, saneamento, saúde e educação; além de poder despertar uma maior consciência ambiental nos moradores e nos turistas. Assim, a hipótese levantada no presente trabalho, é de que a Barra do Ribeira apresenta uma grande potencialidade para o desenvolvimento do Turismo Sustentável, porém a falta de articulação entre os setores da sociedade que atuam no local e as restrições legais da Estação Ecológica Juréia - Itatins têm dificultado o processo de desenvolvimento do turismo.

Para o levantamento das questões identificadas foram realizadas pesquisas bibliográficas em jornais, artigos, livros, revistas, Internet, dissertações, documentos oficiais e na legislação ambiental. As fontes primárias foram obtidas através de visitas ao local e entrevistas com a população local, envolvida com o processo turístico.

O primeiro capítulo deste trabalho traz um breve histórico sobre a região da Barra do Ribeira, de forma a abordar os aspectos sociais e ambientais do local, onde tais aspectos serão analisados sob a ótica do conceito de sustentabilidade, fazendo observações sobre a importância do Turismo como forma para alcançar os objetivos de um desenvolvimento sustentável. Sobre esta questão, são abordados assuntos tais como o envolvimento da população local no planejamento e no exercício da atividade turística; a necessidade de elaboração de políticas públicas para o fomento do turismo assim como a interação entre todos os setores envolvidos.

O segundo capítulo por sua vez, trata dos projetos de turismo e desenvolvimento sustentável realizados na região que envolve a Barra do Ribeira, onde são destacadas as ações realizadas pelos projetos Pólo Ecoturístico Lagamar, Agenda do Ecoturismo do Vale do Ribeira e Museu Vivo do Fandango. De modo a ressaltar os conceitos de participação local e interação entre os setores, citados no capítulo anterior, este capítulo aborda também as entidades que atuam na Barra do Ribeira. 
O terceiro capítulo traz uma descrição dos problemas da Barra do Ribeira, como a saúde, a infra-estrutura básica assim como uma breve caracterização sobre os atrativos e a infra-estrutura turística da Barra do Ribeira. Por fim, nas considerações finais são apresentadas as sugestões para a melhoria do turismo na Barra do Ribeira. 


\section{CAPÍTULO 1: Uma análise sócio- ambiental da Barra do Ribeira}

Neste capítulo é feita uma análise histórica, a partir de dados sociais e ambientais da região e da área onde se situa o bairro da Barra do Ribeira, além de conceituar as unidades de conservação onde está inserido o bairro e algumas observações sobre o turismo em áreas próximas às unidades de conservação.

O bairro da Barra do Ribeira, em Iguape - SP está localizado na foz do Rio Ribeira, um vilarejo localizado em uma área de grande importância ambiental, o Complexo Estuarino Lagunar LAGAMAR ${ }^{2}$, um dos cinco mais importantes estuários do mundo, em uma região que se estende por uma faixa de $200 \mathrm{~km}$ em linha reta; englobando Iguape até Paranaguá, no Paraná; considerado como um dos mais produtivos do planeta e sua extensão abrange parte dos $7 \%$ que restaram da maior área contínua de Mata Atlântica do Brasil.

O LAGAMAR é uma das regiões onde o Governo do Estado de São Paulo tem concentrado esforços em questão de desenvolvimento sustentável, devido aos baixos Índices de Desenvolvimento Humano numa região que antigamente era considerada um importante pólo econômico.

A cidade de Iguape passou por diversas fases de desenvolvimento, como os ciclos de ouro e arroz, tornando-se um grande porto de exportação do produto. No entanto, em agosto de 1827 foi iniciada a abertura do Canal do Valo Grande, onde até essa época, todo o transporte de sacas de arroz era feito em canoas até o Porto do Ribeira e dali eram transportadas em carroças até o Porto de lguape (Porto Grande). Para facilitar o transporte das sacas e também reduzir as despesas com fretes, decidiram abrir esse canal que só foi totalmente terminado por volta de 1852, quando então possibilitava acesso a uma canoa por vez.

\footnotetext{
2 Termo utilizado para designar "depressões no fundo do mar e de rios" ou "lagoas de água salgada" SOS Mata Atlântica disponível em: http://:www. sosribeira.org.br. Acesso em 06 de janeiro de 2007
} 
Com o tempo, as margens começaram a desbarrancar, devido à força das águas do Rio Ribeira que passaram a entrar pelo canal, e essa areia começou a ser depositada em frente ao Porto de Iguape, o que aos poucos, foi impedindo a entrada de navios, a obra revelou-se fatal para a economia de lguape ${ }^{3}$.

Atualmente a economia da cidade está estagnada e decadente, onde a cidade vive de atividades como a cultura da banana, extração clandestina do palmito, pesca, construção civil (casas de veraneio) e ainda que de forma incipiente o turismo (PONTES \& QUEIROZ, 1996:27).

Junto a questão de estagnação econômica, a região foi objeto de instrumentos legais para a conservação da Mata Atlântica durante três décadas, como por exemplo, no Decreto Estadual ํㅜ 31.650, de 8 de abril de 1958 que instituiu a Reserva Estadual dos Itatins, uma área de 12.058 hectares de terras declaradas devolutas na vertente atlântica da área montanhosa da Serra do Itatins. A área do Maciço da Jureia, por sua vez, foi doada à Secretaria do Meio Ambiente do Estado de São Paulo por um empreendimento imobiliário, que pretendia implantar um loteamento "ecológico" para abrigar 70.000 pessoas, o que levou pessoas a se empenharem para a preservação do Maciço da Juréia. Em 12 de dezembro de 1977 foi declarado o tombamento do Maciço da Juréia através da Resolução no 11 do Conselho de Defesa do Patrimônio Histórico, Artístico e Turístico (CONDEPHAAT) da Secretaria de Cultura do Estado de São Paulo; sendo registrado como área cultural de interesse cênico e cientifico ${ }^{4}$. Também havia planos do Governo Brasileiro, através da Empresas Nucleares Brasileiras (NUCLEBRÁS), de construir as usinas nucleares Iguape 4 e 5, em uma área de 23.600 hectares, onde posteriormente seria criada a Estação Ecológica Juréia -Itatins, chegando a realizar pesquisas na região e obras de melhoria nas estradas locais (NETO: 2004: 13).

Diante de tais ameaças, a região que abrange o município de Iguape, foi regulamentada como Área de Proteção de Ambiental Cananéia - Iguape - Peruíbe

\footnotetext{
${ }^{3}$ Câmara Municipal de Iguape. Disponível em: http://www.camaraiguape.sp.gov.br. Acesso em: 23 janeiro de 2007

${ }^{4}$ Juréia - Disponível em:http://www.jureia.com.br. Acesso em: 25 de janeiro de 2003
} 
(APA/CIP) pelo Decreto Federal 90.347, de 23 de outubro de $1984^{5}$ e complementada pelo decreto $n^{\circ} 91.892$ de 06 de novembro de 1985. O artigo $2^{\circ}$ do Decreto Federal objetiva:

a) possibilitar às comunidades caiçaras o exercício de suas atividades, dentro dos padrões estabelecidos historicamente;

b) conter a ocupação das encostas passiveis de erosão

c) proteger e preservar os ecossistemas, desde os manguezais das faixas litorâneas, até as regiões de campo, nos trechos de maiores altitudes; as espécies ameaçadas de extinção; as áreas de nidificação de aves marinhas e de arribação; os sítios arqueológicos; os remanescentes da floresta atlântica; a qualidade dos recursos hídricos.

A criação desta Unidade de Conservação teve o objetivo de preservar o Vale do Ribeira e a porção do Litoral Sul do Estado de São Paulo, junto com a intenção de desenvolver de forma sustentável a região mais pobre do Estado de São Paulo.

Dessa forma, com a regulação da APA/CIP foi impossibilitada a execução de qualquer projeto que poderia destruir parte da Mata Atlântica ali encontrada, devido às restrições e proibições para certas atividades capazes de alterar o ecossistema presente e durante esse processo foi reivindicada por ambientalistas a criação de uma Estação Ecológica na região.

Assim, a Estação Ecológica Juréia - Itatins (EEJI) compreendida inteiramente pela APA/CIP, com uma área de aproximadamente 80.000 hectares, foi instituída em 1986, pois a retirada desordenada das usinas da Empresas Nucleares Brasileiras (NUCLEBRÁS) poderia causar mais especulação imobiliária na Juréia, trazendo uma maior degradação à área em que foram destinados esforços por parte de ambientalistas brasileiros para a sua conservação. A EEJI compreende o maciço montanhoso da Juréia e a planície costeira, preservando a Mata Atlântica e seus ecossistemas associados de praia, costão rochoso, manguezal, restinga, banhado e vegetação de

\footnotetext{
${ }^{5}$ Secretaria do Estado do Meio Ambiente: Regulamentação da APA Cananéia -lguape-Peruíbe: plano de gestão/ ZEE, pp. 23
} 
altitude, considerada o coração da zona mais preservada da Mata Atlântica ${ }^{6}$. Cabe destacar que a luta dos ambientalistas contra a instalação de usinas da Nuclebrás foi bem sucedida, conseguindo proteger os ecossistemas locais, porém mesmo com a desapropriação dos terrenos, naquele tempo viviam dentro da Juréia, diversas famílias de caiçaras, o que colidia com a legislação de uma Estação Ecológica, que é uma Unidade de Conservação de Proteção Integral, categoria esta que não permite a presença humana dentro dos seus limites e tão pouco o uso direto de seus recursos naturais.

Instaurou-se então um conflito social dentro da recém criada Estação Ecológica, pois alguns dos moradores tradicionais sofreram grandes pressões por parte dos policiais, não foram indenizados e muito menos realocados; migrando voluntariamente para regiões próximas, inclusive a Barra do Ribeira (NUNES: 2003), pois já não podiam mais exercer as atividades extrativistas de subsistência, como a extração do palmito, enfraquecendo assim a economia e a tradição caiçara. Os migrantes da Juréia tiveram que encontrar fontes de renda alternativas, através de trabalhos temporários, como o turismo. Na época foi oferecida para alguns caiçaras do interior da EEJI a função de guarda -parque, o que causou mais atritos, pois como a população caiçara tem base no apadrinhamento e em relações de parentesco, os moradores que queriam ser indenizados e ter o direito de voltar a exercer suas atividades entraram em embates com familiares que se "beneficiaram" com a função de guarda-parque. ${ }^{7}$

Vale observar que o Parágrafo Único do artigo 28 do Sistema Nacional de Unidades de Conservação $(\text { SNUC) })^{8}-2000$ faz as seguintes ressalvas:

Parágrafo único. Até que seja elaborado o Plano de Manejo, todas as atividades e obras desenvolvidas nas unidades de conservação de proteção integral devem se limitar àquelas

\footnotetext{
${ }^{6}$ MONGUE - Disponível em: http://www.mongue.org.br. Acesso em: 17 de janeiro de 2007

${ }^{7}$ Trecho da entrevista realizada na Sede do IBAMA em Iguape, com Dauro Prado Jr, diretor da AJJ em 11de janeiro de 2007.

${ }^{8}$ Sistema Nacional de Unidades de Conservação instituído pela Lei no 9.985 de 18 de junho de 2000.
} 
destinadas a garantir a integridade dos recursos que a unidade objetiva proteger, assegurando-se às populações tradicionais porventura residentes na área as condições e os meios necessários para a satisfação de suas necessidades materiais, sociais e culturais.

As perspectivas de desenvolvimento da região, de certa forma foram prejudicadas com a implantação destas unidades de conservação, a população que possuía suas atividades restritas à caça, à pesca e à agricultura, se encontrou diante de um grande desafio de sobrevivência. No final da década de 70, a Barra do Ribeira já começava a apontar alguns sinais de se tornar um destino turístico, com a facilidade de acesso oferecida pelo funcionamento do "ferry boat" que liga a Praia do Leste em Iguape à Barra do Ribeira.

A população que vivia na Barra do Ribeira, que também executava atividades ligadas à agricultura e à pesca, sofreu grandes impactos quando o turismo começou a ser explorado na região, pois não eram capacitados profissionalmente e se sentiram excluídos do processo. O turismo era movimentado apenas por veranistas (segunda residência), que acabaram sendo os principais responsáveis pelo incremento do comércio e outras atividades relacionadas ao turismo na região, sendo que foram os mais beneficiados pela atividade turística, e que poucas vezes contratavam a mão de obra local.

Aos poucos, os moradores tradicionais da Barra do Ribeira foram participando da atividade turística, oferecendo serviços de caseiro ou até mesmo alugando suas próprias casas para temporada ou finais de semana, atividade que até hoje continua sendo a maior fonte de renda junto com a pesca da manjuba, em que aproveitam a alta temporada, de dezembro à fevereiro, para tirar o sustento do ano inteiro.

De acordo com PONTES \& QUEIROZ (1996:28), o litoral sul, onde a Barra do Ribeira se localiza, era um dos últimos refúgios intocados quando todo o resto da planície costeira do Estado de São Paulo já havia sido ocupada. Pode-se dizer que o turismo trouxe à Barra do Ribeira vantagens (empregos sazonais) e desvantagens, entre elas a degradação ambiental e a descaracterização do meio e da sociedade local com a introdução de hábitos e costumes diferentes dos nativos. 
Através da descrição da situação inicial da atividade turística na Barra do Ribeira, pode-se fazer um apontamento acerca do turismo como instrumento de inclusão social e conservação do patrimônio natural e cultural, proporcionando um desenvolvimento sustentável na localidade.

\subsection{Turismo e Desenvolvimento Sustentável: preservando o patrimônio e} envolvendo a populacão local através de políticas públicas.

A criação de uma Unidade de Conservação pode significar uma perda para as comunidades que vivem na área na medida em que se restringe o acesso à área e seus recursos. A exclusão da comunidade do processo de criação e gestão das unidades de conservação faz com que ela se coloque como opositora da unidade, assim sem o apoio local, se torna difícil conter a depredação da área. Identifica-se que o desafio consiste em encontrar novas atividades econômicas que compatibilizem com a unidade de conservação proposta.

A atividade turística possui diversos segmentos que variam conforme o tipo de atividade desenvolvida nas viagens, sobretudo o objetivo de cada indivíduo. Esse processo é denominado segmentação do turismo, como por exemplo, turismo religioso, turismo cultural, turismo de eventos, turismo histórico, turismo esportivo, ecoturismo, dentre outros, que por sua vez não são excludentes entre si.

Os benefícios da atividade turística não são somente econômicos, mas de grande alcance social, uma vez que representam o estímulo constante ao desenvolvimento de novas infra-estruturas de serviços e favorecem a ampliação da instrução, pela constante demanda de profissionalização necessária ao atendimento das diferentes atividades turísticas.

Por sua vez, o conceito de desenvolvimento sustentável, utilizado desde a elaboração do relatório "Nosso Futuro Comum" em 1987, pela Primeira Ministra da Noruega, Gro Harlem Brundtland da Comissão Mundial sobre Meio Ambiente e Desenvolvimento trata de três vertentes principais:

- crescimento econômico;

- eqüidade social, 
- equilíbrio ecológico.

O Relatório Brundtland define desenvolvimento sustentável como:

\begin{abstract}
"aquele que responde às necessidades do presente sem comprometer a capacidade das gerações futuras de responder às suas necessidades"9
\end{abstract}

A conceituação de um turismo sustentável, ou seja, aquele que promove o turismo e desenvolve uma localidade turística de acordo com os princípios da sustentabilidade, é muito similar ao termo ecoturismo, cuja designação feita pela EMBRATUR e pelo Ministério do Meio Ambiente define como:

Um segmento da atividade turística que utiliza, de forma sustentável, o patrimônio natural e cultural, incentiva sua conservação e busca da formação de uma consciência ambientalista através da interpretação ambiente, promovendo o bem- estar das populações."10

Como promoção do bem-estar das populações, pode-se entender que a distribuição dos benefícios resultantes das atividades turísticas deve contemplar as comunidades receptivas, de modo a torná-las protagonistas do processo de desenvolvimento da região, sendo que a Declaração de Quebec de $2002^{11}$ reconhece que "o ecoturismo tem liderado a introdução de práticas sustentáveis no turismo".

Porém é válido destacar a diferença entre ecoturismo e turismo sustentável, sendo que de acordo com a OMT e o Programa das Nações Unidas para o Meio Ambiente (PNUMA), o ecoturismo é um segmento do turismo, enquanto os princípios

\footnotetext{
${ }^{9}$ Comissão Mundial sobre Meio Ambiente e Desenvolvimento. Nosso Futuro Comum. 1991

${ }^{10}$ Ministério do Turismo. Segmentação do Turismo. Marcos Conceituais.2003

${ }^{11}$ Declaração do Ecoturismo de 2002. Documento aprovado pelo Programa de Meio Ambiente das Nações Unidas e Organização Mundial do Turismo (OMT).
} 
da sustentabilidade almejados para o Turismo Sustentável são aplicáveis e devem servir de premissa a todos os tipos de turismo em quaisquer destinos ${ }^{12}$.

De acordo com Swarbrooke (2000, p.14), o Turismo Sustentável:

estimula uma compreensão dos impactos do turismo nos ambientes natural, cultural e humano; incorpora planejamento e zoneamento assegurando o desenvolvimento do turismo adequado à capacidade de carga do ecossistema; demonstra a importância dos recursos naturais e culturais e pode ajudar a preservá-los.

Para que o objetivo do desenvolvimento sustentável seja alcançado através do turismo, muitos autores, como Brandon (2002:228), apontam que a participação da comunidade local é fundamental para o processo de um planejamento turístico em áreas próximas a unidades de conservação, como no caso da Barra do Ribeira, pois permite que a comunidade assuma o controle do desenvolvimento trazendo benefícios para a comunidade (idem: 232). Segundo a autora, participação local significa:

dar às pessoas mais oportunidades de participar efetivamente nas atividades de desenvolvimento, proporcionando condições para que elas mobilizem seu próprio potencial, sejam agentes sociais em vez de sujeitos passivos, gerenciem os recursos, tomem decisões e controlem as atividades que afetam sua vida.

Segundo Lacorte \& Ribeiro (2003), para que possa haver uma gestão social do turismo, alguns fatores devem ser levados em consideração, tanto por parte da iniciativa privada quanto da iniciativa pública:

- Planejar e coordenar a atividade turística de modo que esta possa se desenvolver ordenadamente e de forma sustentável;

\footnotetext{
12 ibidem
} 
- Avaliar a oferta da mão-de-obra local, de modo que seja suficiente para atender a demanda turística;

- Construir com a população local, conscientização ambiental, capacitação e qualificação adequada para o trabalho;

- Proporcionar a participação de todos os setores da sociedade no processo turístico;

- Estimular a produção e o consumo de produtos regionais, de forma que a atividade turística seja propulsora da economia local;

- Reverter porcentagem do dinheiro recebido com a atividade turística para atividades sociais e ambientais.

- Gerenciar os meios de transportes e as condições de tráfego;

- Conservação de energia e água;

- Tratamento da água utilizada de maneira a não causar poluição

Baseando-se nas citações mencionadas, nota-se que tanto para o exercício da atividade turística como para a implantação de unidades de conservação é necessário que haja a o envolvimento da comunidade local para assegurar que os impactos sociais e ambientais sejam amenizados. Observa-se que esta questão se torna mais urgente, devido à existência de populações tradicionais na região da Barra do Ribeira.

De acordo com Adams (2001):

entende-se por populações tradicionais aquelas que apresentam um modelo de ocupação do espaço e uso dos recursos naturais voltado principalmente para a subsistência, com fraca articulação com o mercado, baseado em uso intensivo de mão de obra familiar, tecnologias de baixo impacto derivadas de conhecimentos patrimoniais e, normalmente, de base sustentável.

Segundo a autora, um aspecto relevante na definição de populações tradicionais é a existência de sistemas de manejo dos recursos naturais marcados pelo respeito aos ciclos naturais. Inclusive sustenta-se a idéia de que as características da cultura caiçara são importantes, pois permitem a manutenção e conservação dos próprios recursos naturais de que dependem para sobreviver. 
Para Lima \& Gita (2001:4):

as populações tradicionais não se reconhecem como tal, porém devem ser vistos como sujeitos políticos, conscientes de sua identidade, capazes de se organizar para defender seus interesses e de se relacionar com diversas instituições. São grupos de direito - direito a ter direitos, seja ao território, a matérias primas, à preservação do seu modo de ser, à sua cultura e devem em contrapartida promover o uso sustentável do ambiente natural em que vivem.

A participação local vista como um processo, vai muito além da simples divisão de benefícios sociais e econômicos. Contempla a capacitação de pessoas, incentivando sua mobilização, e que administrem os recursos, tomem decisões e controlem as atividades que afetam suas vidas. Esse processo funciona como um catalisador para estimular a autoconfiança da comunidade, enfatizando a importância da participação das instituições locais, tanto formais quanto informais (KINKER: 2002:45).

Utilizando a união das tradições da população caiçara e das intenções de desenvolvimento, pode-se esperar alguns benefícios oriundos do turismo, aspectos como a sustentabilidade, a educação patrimonial, a criação de uma consciência para a preservação do patrimônio histórico e da diversidade cultural. É oportuno estimular a comunidade a conhecer suas origens, a perceber sua importância, e repassar seus saberes e história para as gerações futuras.

Para que a concepção do turismo sustentável seja possível, nota-se também a necessidade de políticas públicas voltadas para sua aplicação, de forma a garantir o cumprimento dos objetivos buscados pela sustentabilidade. Somente com a participação de todos os níveis de governo, Federal, Estadual, Municipal, representantes de todos os segmentos da sociedade, organizações não governamentais e o trade turístico, o turismo atingirá integralmente suas metas. É com a formulação de políticas intersetoriais conjuntas direcionadas ao turismo, que as ações podem ser guiadas com diretrizes para a execução de um planejamento turístico a 
longo prazo, onde tal planejamento deve ser ecologicamente suportado e direcionar o comportamento dos turistas para a educação ambiental. ${ }^{13} \mathrm{O}$ turismo, que é visto como um componente lógico do desenvolvimento sustentável exige uma abordagem multidisciplinar, regulamentos e regras severas para garantir a sustentabilidade da operação.

Diversos setores do governo, assim como empresas privadas e universidades, reconhecem a importância da atividade turística para o desenvolvimento sustentável, elaborando assim documentos contendo diretrizes para a prática de um turismo consciente, como por exemplo, as "Diretrizes para uma Política Nacional de Ecoturismo" publicado em 1994 pela EMBRATUR e pelo IBAMA. Com base neste documento, o Governo do Estado de São Paulo elaborou as Diretrizes para uma Política Estadual do Ecoturismo ${ }^{14}$, que tiveram o propósito de formular diretrizes orientadas por certos princípios como: uso sustentável dos recursos naturais; manutenção da diversidade biológica e cultural; integração do turismo no planejamento; suporte às economias locais; envolvimento das comunidades locais; consulta ao público e aos atores envolvidos; capacitação de mão-de-obra; marketing turístico responsável; redução do consumo supérfluo e desperdício e desenvolvimento de pesquisa.

O Governo Estadual de São Paulo, através da Secretaria do Meio Ambiente (SMA) têm se empenhando para aplicar as diretrizes acima mencionadas em todo o seu Estado, pois o turismo vem se caracterizando como um novo segmento econômico na região que abrange a Barra do Ribeira, apresentando novas perspectivas de desenvolvimento ${ }^{15}$, de forma a otimizar os aspectos positivos e minimizar os impactos negativos, onde o planejamento da atividade turística deve estar calcado nos princípios da sustentabilidade. O Governo do Estado de São Paulo pretende incentivar a

\footnotetext{
${ }^{13}$ Revista Turismo, jun-2004. Disponível em: http://www.revistaturismo.com.br. Acesso em 18 de fevereiro de 2007

${ }^{14}$ Documento elaborado em 1997 pela Coordenadoria de Educação Ambiental - CEAM, em parceria com a Secretaria Estadual do Meio Ambiente - SMA e a Unicamp.

15 Estado de São Paulo. Secretaria do Meio Ambiente. PROJETO DE DESENVOLVIMENTO DO ECOTURISMO NA REGIÃO DA MATA ATLÂNTICA. Estudo Ambiental. 2005
} 
participação comunitária das comunidades locais nas operações turísticas, para que estas sejam consideradas como uma atividade econômica viável, sustentável e complementar às suas economias.

O IBAMA, por sua vez, identifica que os benefícios econômicos, sociais e ambientais do ecoturismo são: diversificação da economia regional; geração local de empregos; fixação da população no interior; melhorias na infra-estrutura de transporte, comunicação e saneamento; criação de alternativas de arrecadação para as unidades de conservação. Porém ressalva que só haverá condições de sustentabilidade da atividade turística, caso haja harmonia e equilíbrio entre os seguintes fatores: resultados econômicos, mínimos impactos ambientais e culturais, e satisfação do cliente (turista) e da comunidade ${ }^{16}$.

O Plano Gestor da APA- CIP, elaborado pelo IBAMA/ SMA, entre outros órgãos do Estado de São Paulo, faz referências a uma maior participação da comunidade local, criando comitês gestores, de forma a viabilizar as condições futuras para a gestão da APA-CIP, definindo uma estrutura de gestão integrada, participativa e descentralizada, onde uma das atribuições mais importantes do Comitê Gestor é a possibilidade de deliberar sobre documentos e propostas encaminhadas pela comunidade ${ }^{17}$.

Reconhecida a importância do turismo como capaz de proporcionar um desenvolvimento sustentável, essas observações se tornam ainda mais essenciais, em virtude da transformação da EEJI em um mosaico de áreas protegidas, onde a aprovação desta lei ${ }^{18}$ que criou a Reserva de Desenvolvimento Sustentável do Despraiado (Iguape) foi uma grande vitória para a população remanescente na Estação Ecológica, que através da formação de associações, como a União dos Moradores da

\footnotetext{
${ }^{16}$ Secretaria do Estado do Meio Ambiente: Regulamentação da APA Cananéia -Iguape-Peruíbe: Plano de gestão/ ZEE, pp. 39

18 Lei Estadual no 12406 de 12 de dezembro de 2006. Disponível em: http://www.ambiente.sp.gov.br/destaque/2006/conv consulta publica/justificativa.pdf. Acesso em: 05 de janeiro de 2007
} 
Juréia (UMJ) lutaram por 20 anos, para ter o direito de permanecer dentro da Juréia e ter a possibilidade de continuar as atividades de subsistência.

E ainda mais importante para os moradores da Barra do Ribeira é a classificação da área do Prelado em Parque Estadual, pois está situado no extremo Sul da atual Estação, abrangendo uma faixa costeira da Praia da Juréia, com sete quilômetros de extensão e a planície costeira contígua à praia. A área conta com vasta extensão de vegetação bem conservada e baixa presença humana, apresentando um conjunto de ambientes de planície e restinga, assentado nos cordões e entre-cordões arenosos. Nos limites da área encontra-se a Vila do Prelado, habitada por pescadores e prestadores de serviços às residências e loteamentos situados ao longo da Praia da Juréia, em seus 22 quilômetros que levam à foz do Rio Ribeira de Iguape. 


\section{CAPÍTULO 2: Projetos de Turismo e Desenvolvimento Sustentável na Barra do Ribeira}

Como foi explicitado no capítulo anterior, para que o turismo seja considerado uma atividade sustentável, capaz de proporcionar uma melhoria de vida nas populações tradicionais, é necessário que além da participação da comunidade no processo de desenvolvimento da atividade turística, seja feito o planejamento desta atividade. Tal planejamento deve estar baseado em políticas públicas que impulsionem os projetos de turismo. Sendo assim, neste capítulo serão abordados alguns projetos que tratam das diretrizes para o desenvolvimento sustentável e o turismo no município de Iguape e região, embora a maioria deles não tenha contemplado especificamente o bairro da Barra do Ribeira.

Verifica-se a preocupação em direcionar políticas de desenvolvimento sustentável na região do LAGAMAR, onde, em 1985, a extinta Superintendência de Desenvolvimento do Litoral Paulista - SUDELPA, órgão responsável pelo desenvolvimento e organização das ações de planejamento do Litoral Paulista, elaborou um Plano Básico de Desenvolvimento Auto-Sustentado da Região Lagunar de Iguape - Cananéia ${ }^{19}$, de forma a implementar programas e projetos para a região. $\mathrm{O}$ objetivo deste plano era fomentar atividades compatíveis com a preservação do patrimônio natural do local.

Para SUDELPA (1987:19), porém, na época, a atividade turística, junto com a pesca foi identificada como um grande desafio na região, devido à dependência dos recursos naturais, levantando uma grande questão de como compatibilizar o crescimento do turismo com a necessidade de conservar os recursos naturais. Alguns obstáculos foram observados tais como: a ocupação desordenada, pressão crescente sobre os recursos naturais renováveis, expropriação da população local das suas terras, falta de novas oportunidades de trabalho, falta de infra-estrutura de serviços para as populações locais e perda de identidade cultural. Embora não tenham ocorrido ações

19 São Paulo (Estado). Secretaria de Estado dos Negócios do Interior. Superintendência do Desenvolvimento do Litoral Paulista - SUDELPA. Plano Básico de Desenvolvimento Auto-Sustentado para a região lagunar de Iguape- Cananéia. São Paulo, 1987. 
específicas voltadas para a atividade turística, este plano apontou a necessidade de projetos de infra-estrutura básica para evitar a degradação ambiental para, posteriormente, desenvolver propostas no setor turístico.

De acordo com a SOS Mata Atlântica (2004:15), a demanda por serviços turísticos deu origem às primeiras iniciativas de investimento em organização, capacitação de atores e de instituições locais e externas, onde, em meados da década de 90 ocorreu com iniciativa da Universidade de São Paulo (USP), o primeiro curso para monitores ambientais no Lagamar, que formou cerca de 200 monitores.

Foram realizados diversos projetos na região do Vale do Ribeira e do Lagamar, devido à sua importância no contexto de preservação da biodiversidade e do reconhecimento de seu potencial turístico; levando em consideração também suas características sociais. A tabela a seguir mostra alguns planos e projetos propostos para a área:

QUADRO 1 - PROJETOS REALIZADOS

\begin{tabular}{|c|c|}
\hline PROJETOS & INSTITUIÇŌES RESPONSȦVEIS \\
\hline $\begin{array}{l}\text { PLATAFORMA AMBIENTAL MÍNIMA PARA } 0 \\
\text { DESENVOLVIMENTO SUSTENTÁVEL DO VALE DO } \\
\text { RIBEIRA }\end{array}$ & VITAE CIVILLIS \\
\hline $\begin{array}{l}\text { PROGRAMA DE FORTALECIMENTO DAS } \\
\text { VOCAÇÕES DAS COMUNIDADES RURAIS DO VALE } \\
\text { DO RIBEIRA - Agenda Rural }\end{array}$ & $\begin{array}{l}\text { ORGÃOS DO GOVERNO DO ESTADO DE } \\
\text { SÃO PAULO (COMISSÃO GESTORA) }\end{array}$ \\
\hline $\begin{array}{l}\text { PROJETOS DE EXECUÇÃO DESCENTRALIZADA } \\
\text { (PED) }\end{array}$ & $\begin{array}{l}\text { MINISTÉRIO DO MEIO AMBIENTE } \\
\text { SECRETARIA DO MEIO AMBIENTE DO } \\
\text { ESTADO DE SÃO PAULO }\end{array}$ \\
\hline AGENDA DE ECOTURISMO DO VALE DO RIBEIRA & \begin{tabular}{lccc} 
CENTRO DE & \multicolumn{2}{c}{ ESTUDOS } & DE \\
ADMINISTRAÇÃO & PÚBLICA & (CEPAM), \\
SECRETARIAS DO & ESTADO & DE SÃO \\
PAULO, CODIVAR & & &
\end{tabular} \\
\hline $\begin{array}{l}\text { FÓRUM DE DESENVOLVIMENTO DO VALE DO } \\
\text { RIBEIRA }\end{array}$ & GOVERNO DO ESTADO DE SÃO PAULO \\
\hline $\begin{array}{l}\text { PROJETO GESTÃO PARTICIPATIVA PARA O USO } \\
\text { DOS RECURSOS PESQUEIROS NO COMPLEXO }\end{array}$ & IBAMA \\
\hline
\end{tabular}




\begin{tabular}{|l|l|}
\hline $\begin{array}{l}\text { ESTUARINO LAGUNAR IGUAPE, CANANÉIA, ILHA } \\
\text { COMPRIDA }\end{array}$ & \\
\hline PÓLO ECOTURÍSTICO DO LAGAMAR & SOS MATA ATLÂNTICA \\
\hline $\begin{array}{l}\text { PLANO DE DESENVOLVIMENTO SUSTENTÁVEL DO } \\
\text { VALE DO RIBEIRA }\end{array}$ & $\begin{array}{l}\text { INSTITUTO PARA O DESENVOLVIMENTO } \\
\text { SUSTENTÀVEL E CIDADANIA DO VALE DO } \\
\text { RIBEIRA }\end{array}$ \\
\hline MUSEU VIVO DO FANDANGO & $\begin{array}{l}\text { MINISTÉRIO DA CULTURA, PETROBRÁS E } \\
\text { ASSOCIAÇÃO DOS JOVENS DA JURÉIA }\end{array}$ \\
\hline
\end{tabular}

Fonte: Fabianne Ykemoto

Sendo assim destacam-se três projetos: o Pólo Ecoturístico Lagamar, a Agenda de Ecoturismo do Vale Do Ribeira e Museu Vivo do Fandango. O critério para escolha por estes projetos foi por dois deles terem o foco no turismo e o outro projeto por estimular a valorização da cultura caiçara. Observa-se que os projetos de turismo tiveram interação entre eles devido ao objetivo central de desenvolver a região do Vale do Ribeira.

Os dois projetos de turismo foram realizados na mesma época, em 1995, a partir da realização do seminário Plataforma Ambiental para o Desenvolvimento Sustentável do Vale do Ribeira, onde o turismo se apresentava como um dos temas estratégicos, estimulando debates a cerca dos princípios orientadores da atividade, dos padrões a serem adotados; da definição da capacidade de suporte turístico; a realização de estudos e de debates sobre as formas de retribuição de benefícios para as instâncias locais; a realização de campanhas de educação ambiental para os turistas e o reforço do saneamento ambiental.

No mesmo período, a Embratur, em parceria com o Instituto de Ecoturismo do Brasil - IEB, desenvolveu uma pesquisa que tinha como objetivo identificar as localidades brasileiras onde a prática do ecoturismo já vinha ocorrendo com algum sucesso e fazer um levantamento das características, das potencialidades e das condições de infra-estrutura nos locais onde o turismo se apresentava como uma nova alternativa de desenvolvimento. Esta pesquisa que deu origem em 1997 ao documento "Pólos de Desenvolvimento de Ecoturismo no Brasil", onde foram identificados 96 pólos potenciais para o desenvolvimento da atividade, com um projeto inicial para planejamento de dez deles, onde se inclui a região do Lagamar (KINKER: 2002:85). 
Na região do Lagamar, foi implementado pela S.O.S Mata Atlântica, com o apoio da EMBRATUR, o Pólo Ecoturístico do Lagamar (PEL) que envolvia as comunidades dos municípios de Iguape, Ilha Comprida, Cananéia e Pariquera- Açu. O PEL teve como principal objetivo promover e desenvolver o turismo na região aproveitando seu potencial, de forma a sensibilizar os turistas e a comunidade local para a valorização e conservação dos recursos naturais e culturais. De acordo com Magalhães (1998:96), o projeto Pólo Ecoturístico do Lagamar teve como critérios norteadores:

- a adoção de estratégias para um planejamento sustentável, considerando os aspectos ambientais, sociais e econômicos;

- o envolvimento dos atores locais, buscando gerar emprego e renda e melhoria da qualidade de vida, privilegiando sua capacitação profissional;

- a utilização das infra-estruturas físicas já existentes, adaptando os meios de hospedagem, transporte, restaurantes, e demais serviços turísticos existentes nos municípios, às exigências do mercado consumidor;

- a percepção de que as práticas de atividades ecoturísticas podem contribuir para a educação ambiental do turista, do empresário, do administrador público e da comunidade local.

Como medidas práticas o Projeto criou uma rede de 27 agentes emissivos baseados na capital de São Paulo, que intermediavam ou operavam roteiros ecoturísticos em parceria com os agentes receptivos do Lagamar, previamente cadastrados. Os programas ecoturísticos colocados a disposição do público procuraram sempre a integração dos destinos como forma de atrair a permanência do turista, não só em um único município, mas em toda o região do Pólo do Lagamar (MAGALHÃES:2001:62 ).

Foi montado um leque de produtos ecoturísticos e criada uma rede de destinos. Pacotes turísticos estrategicamente distribuídos e desenvolvidos de forma seqüencial foram preparados incluindo caminhadas, passeios de caiaque, trilhas para bicicleta, observação de fauna, oferecidos à estudantes do ensino médio, famílias, grupos de 
terceira idade e de turismo de aventura, com a duração media de três dias. Outro objetivo do projeto dizia a respeito a qualificação dos serviços prestados, tanto pelos agentes emissivos, como pelos operadores receptivos.

De acordo com as informações extraídas do estudo de caso realizado pela SOS Mata Atlântica, o projeto foi executado em quatro fases:

- primeira fase: junho/1995 - junho/1996

- segunda fase: julho/1996 - dezembro/1996

- terceira fase: janeiro/1997 - julho/1997

- quarta fase: novembro/1997 - maio/1998

A primeira etapa do projeto foi contemplada com a visita dos consultores a região para apresentar o projeto, onde foi realizada uma pesquisa de mercado, com o intuito de identificar o perfil dos turistas e também o inventário preliminar de recursos disponíveis, como infra-estrutura receptora, serviços turísticos emissivos, atrativos naturais, históricos, culturais e turísticos; e recursos humanos. A partir do inventário foram elaborados roteiros e a identificação dos futuros parceiros do projeto, como proprietários de pousadas, restaurantes e monitores ambientais. Também foi realizada uma reunião em São Paulo onde foi apresentado e discutido o funcionamento do Projeto, e também os direitos e responsabilidades dos participantes e a necessidade da criação de um Conselho de Auto Regulamentação, composto por representantes dos agentes emissivos, receptivos e pela coordenação do Projeto.

Já na segunda fase, o projeto passou a contar com o patrocínio da EMBRATUR, que reconheceu o pioneirismo da iniciativa e a importância da implantação deste projeto para o desenvolvimento sustentável da região, garantido assim:

- a definição do produto ecoturístico a ser oferecido;

- formação de dois grupos de parceiros de agentes emissivos e receptivos,

- realização de um seminário para jornalistas com o intuito de difundir o projeto pelos meios de comunicação;

- a realização de um workshop com os agentes emissivos para a definição da estratégia operacional do projeto. 
A terceira fase teve suas metas fixadas pelo consenso entre os agentes emissivos, em que foram realizadas diversas reuniões, que definiram três objetivos principais, tais como a capacitação profissional, divulgação publicitária e educação ambiental. Para a capacitação profissional, a Fundação SOS Mata Atlântica, buscou ajuda do SENAC/SP e do Instituto de Ecoturismo do Brasil (IEB) onde se realizaram, diversos cursos técnicos e práticos, além de palestras e seminários nos quatro municípios envolvidos. Outra meta realizada foi de divulgação, com a produção de material interpretativo e informativo sobre o Lagamar, onde foram produzidos um mapa regional, um folheto com informações sobre a história do lugar e os objetivos do projeto, e a publicação do livro Descubra o Lagamar, de Nícia Magalhães, entre outras formas de divulgação.

$\mathrm{Na}$ quarta fase do projeto foi implantado um Centro de Interpretação Ambiental e Informações Turísticas no Centro Histórico de Iguape, que funciona como base da SOS Mata Atlântica. O local conta com atrativos que fornecem dados sobre a importância da região, como uma maquete detalhada, além de painéis explicativos sobre aspectos do Lagamar. Em alguns pontos da cidade, como lanchonetes, estão espalhados panfletos sobre o Centro de Interpretação, permitindo o conhecimento do local, porém só realmente quem passa por Iguape ou procura informações sobre o Lagamar sabe da existência do local. O Centro atende estudantes de diversos níveis e contribui para a educação ambiental. A grande distância do centro de lguape para a Barra do Ribeira dificulta o acesso dos turistas que freqüentam a Barra do Ribeira ao Centro de Interpretação, o que prejudica a disseminação dos objetivos do mesmo para aquele público.

No estudo de caso do Projeto Pólo Ecoturístico do Lagamar, a SOS Mata Atlântica identificou os resultados obtidos no projeto, e aponta que, embora as etapas do projeto incentivassem a participação da comunidade no planejamento da atividade turística, as ações direcionadas nesse sentido não foram realizadas de forma a dar suporte à organização comunitária. Além disso, a SOS Mata Atlântica percebeu que a população possui uma postura passiva, depositando suas esperanças em soluções vindas do governo ou de outras instituições, onde na região do Lagamar nem os governos municipais, nem a iniciativa privada demonstraram reconhecer o imenso 
potencial da região e muito menos despertaram para o risco que a falta de planejamento e organização do setor turístico pode representar. (SOS MATA ATLÂNTICA: 2004:46).

Observando o aumento do fluxo do turismo na região devido a diversos fatores como duplicação da rodovia Régis Bittencourt (BR-116) em 1998, que dá acesso à região e a saturação do Litoral norte de São Paulo; a instituição executora do projeto percebeu a necessidade de estruturar ainda mais as comunidades receptoras, pretendendo assim dar continuidade ao Projeto Pólo Ecoturístico do Lagamar; onde irá analisar e sistematizar o processo de desenvolvimento do Projeto, atualizar os dados e informações regionais sobre o tema, através da avaliação da situação atual do turismo; incentivar a gestão participativa do turismo; entre outras ações.

Na mesma linha, a Embratur apoiou outro projeto turístico na região que abrange a Barra do Ribeira, a Agenda de Ecoturismo do Vale do Ribeira; coordenada pelo Centro de Estudos de Administração Municipal (CEPAM) e que conta com a participação de algumas Secretarias do Governo Estadual e seus órgãos técnicos e CODIVAR (consórcio que congrega e representa todos os 24 municípios do Vale); além de diversos segmentos das comunidades. A Agenda de Ecoturismo surgiu a partir da necessidade de planejar um desenvolvimento sustentável para o Vale do Ribeira; onde foi criado assim um programa regional visando o estudo, o planejamento e o fomento do ecoturismo na região, como uma estratégia de desenvolvimento sustentável. Seguindo estes pressupostos, foram determinados como os objetivos da $\mathrm{Agenda}^{20}$ :

a) promover e articular ações de capacitação e educação de pessoal local para as atividades de ecoturismo;

b) realizar levantamento, sistematizar e disponibilizar dados referentes ao ecoturismo e à infra-estrutura básica existente na região;

c) mobilizar recursos de forma complementar, visando implantar e planejar o ecoturismo na região.

\footnotetext{
${ }^{20}$ Instituto de Economia Agrícola: Agenda de Ecoturismo do Vale do Ribeira. 2003
} 
A primeira atividade implementada, contemplando a capacitação como uma das estratégias do plano de ação, foi o programa de treinamento "Agentes Municipais de Ecoturismo", de 1995 a 1996, onde em 1996, iniciou-se uma linha de capacitação, voltada para os Monitores Ambientais. Esta linha de ação foi viabilizada por recursos do Fundo de Amparo ao Trabalhador (FAT) e coordenada pela organização não governamental Instituto Ing-Ong de Planejamento, que capacitou moradores vizinhos às Unidades de Conservação e demais áreas de visitação da região do Vale do Ribeira para atuar como monitores ambientais. Esta capacitação seguiu os conceitos da educação ambiental, aliados ao conhecimento local, viabilizando a geração de trabalho e renda, com a operacionalização de roteiros ecoturísticos existentes, ou em fase de implantação, e o estimulo às ações comunitárias, à educação ambiental e à pesquisa científica.

Através desta ação de capacitação, em 1999 foi criada a Associação dos Monitores Ambientais de Iguape (AMAI) com 28 monitores, a maioria deles moradores da Barra do Ribeira, tiveram aulas sobre educação ambiental, ecoturismo, unidades de conservação, ambiente natural e primeiros socorros, entre outros temas previstos na resolução SMA/SP-32, de 31/03/1998, que define o currículo mínimo obrigatório para o exercício da monitoria ambiental. Os jovens ainda tiveram cursos de elaboração de projetos educacionais; onde se destaca a iniciativa de educação ambiental nas Escolas da Barra do Ribeira, "Criança Natureza: um Futuro Promissor"; técnicas de interpretação ambiental e desenvolvimento de produtos ecoturísticos e fizeram ainda estágio supervisionado na Estação Ecológica Juréia-Itatins ${ }^{21}$. Cabe destacar, que apesar de não ser permitida a realização de turismo dentro de uma Estação Ecológica, os monitores ambientais atendiam ao fim educacional de uma Estação Ecológica, contribuindo assim para a preservação do local, inclusive por ser uma alternativa de vida para estes jovens.

Para alcançar o planejamento turístico, foi realizado o Primeiro Inventário Turístico do Vale do Ribeira em 1998, juntamente com o Bioma Assessoria e Educação Ambiental, a partir do convênio firmado entre a Fundação Florestal do Estado de São

21 Esclarecimentos a Rede CTA-JMA do Instituo Ing-Ong e da AMAl. Disponível em: http://www.ruralnet.com.br/meioambiente/default.asp?noticia=1552. Acesso em 06 jan 2007. 
Paulo e a Embratur. O inventário deu ênfase à elaboração do perfil turístico regional e suas potencialidades, observando:

a) os atrativos naturais da região que têm como fonte os próprios acidentes naturais ou recursos da fauna e da flora;

b) os atrativos culturais relacionados com atividades humanas;

c) os equipamentos e serviços de infra-estrutura turística disponíveis na região.

Neste inventário também foram entrevistados empreendedores de meios de hospedagem, agências de receptivos, prefeitos, diretores das Unidades de Conservação e diretores de organizações não governamentais para levantar suas concepções sobre o desenvolvimento da atividade turística na região.

Com base nos dados obtidos pelo Inventário realizado no Vale do Ribeira, segue um gráfico referente aos meios de hospedagem e serviços no Baixo Ribeira, que compreende os municípios de Cananéia, Iguape, Ilha Comprida, Itariri, Pedro de Toledo e Peruíbe (ROMÃO: 2003):

\section{GRÁFICO 1: EQUIPAMENTOS DE APOIO AO TURISMO NO BAIXO RIBEIRA}

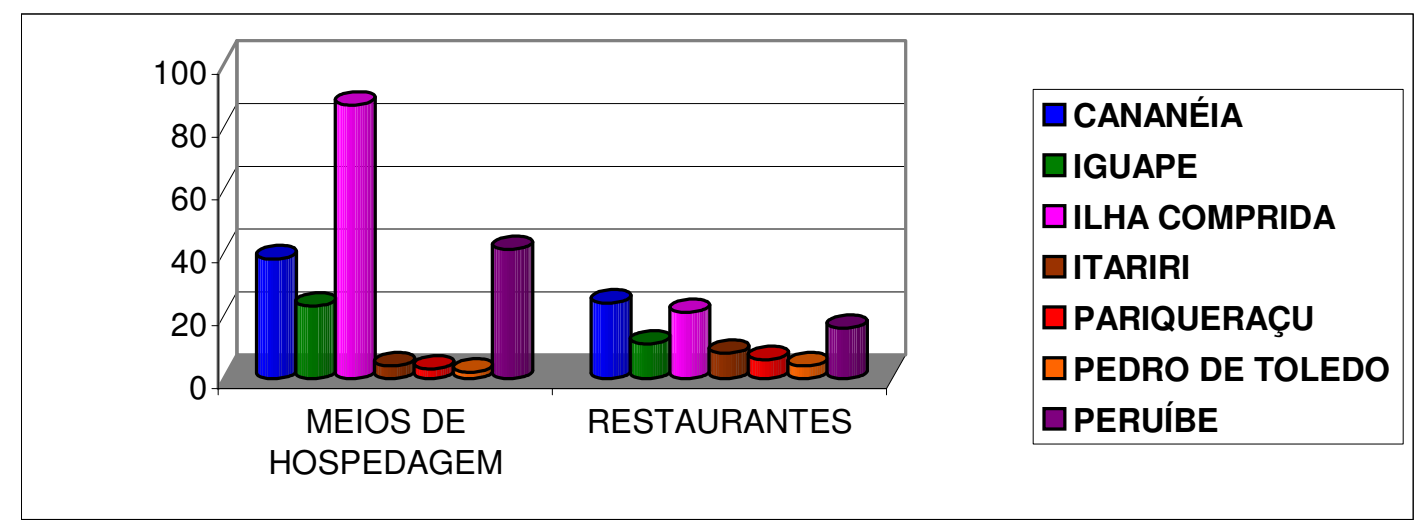

Fonte: Romão (2003)

Como pode ser observado, Iguape está em quarto lugar em termos de equipamentos turísticos na região, sendo superado por Cananéia (38), Peruíbe (41) e 
Ilha Comprida (87). Vale ressaltar que dos dezenove meios de hospedagem de Iguape, sete estão localizados na Barra do Ribeira (CD Ecoturismo na Mata Atlântica).

A partir dos dados obtidos pelo Inventário, foi realizada em 1999, uma Oficina de Avaliação e Planejamento dos trabalhos da Agenda de Ecoturismo do Vale do Ribeira, no Parque Estadual da Ilha do Cardoso. Nesta Oficina participaram representantes de prefeituras de vários municípios do Vale do Ribeira, Organizações Não Governamentais, associações de monitores ambientais, proprietários de pousadas, estudantes de turismo e a equipe da Agenda de Ecoturismo para fazer uma análise dos trabalhos desenvolvidos, observando os avanços e as deficiências.

De acordo com Romão (2004), a Agenda de Ecoturismo teve suas ações realizadas durante nove anos, baseada basicamente na publicação de estudos sobre a região do Vale do Ribeira e também no estímulo para estabelecer parcerias com organizações não-governamentais, associações de base comunitária e prefeituras para a implementação das suas atividades. A atuação da Agenda do Ecoturismo procurou apoiar e desenvolver ações de fomento ao turismo sustentável como estratégia de desenvolvimento local e garantia do bem estar das comunidades, bem como inovar em sua forma de atuação por meio da articulação e mobilização dos atores locais e da descentralização da gestão turística do poder público municipal.

Além dos resultados alcançados pela iniciativa da Agenda do Ecoturismo do Vale do Ribeira, pretendeu-se dar continuidade ao projeto, sendo que as novas etapas do projeto consistem em publicar o "Manual de Turismo Sustentável do Vale do Ribeira". Incluíram-se como ações a médio prazo, a criação de um Sistema de Informação, a partir do Banco de Dados do Inventário Turístico que estará disponível em cada município; realizações de Oficinas de Planejamento Participativo com as comunidades rurais; cuja preferência está no desenvolvimento da renda e do emprego tendo por base o ecoturismo e a elaboração de um Plano de Desenvolvimento Integrado do Turismo Sustentável para a Região do Vale do Ribeira. Verificou-se que para dar continuidade aos trabalhos da Agenda de Ecoturismo do Vale do Ribeira, houve necessidade de articular e integrar com outros órgãos públicos nas três esferas de governo: municipal, estadual e federal. 
Após a breve explicitação dos projetos implantados, pode-se fazer certas observações dos resultados proporcionados para a região. Nota-se que ambos os projetos tiveram uma abrangência muito grande, dificultando um enfoque mais adequado a cada realidade, apesar das questões referentes ao turismo e a qualidade de vida dos municípios serem similares.

Assim a atuação dos projetos foi um tanto superficial para englobar todos os aspectos da atividade turística como instrumento de inclusão social, porém um grande destaque dos projetos foi o reconhecimento de que a região que abrange o município de Iguape merece atenção e planejamento turístico para que haja um desenvolvimento sustentável. Avalia-se assim que as iniciativas obtiveram êxito no sentido de fomentar a participação de todas as esferas relacionadas à questão ambiental e turística, assim como a intenção de envolver e capacitar a população local, inclusive no ponto que se refere à formação de associações.

É importante frisar que qualquer tipo de ação demanda tempo e recursos, e que para ser bem sucedido, os resultados de projetos de turismo e desenvolvimento sustentável devem ser esperados a longo prazo.

Os esforços destes projetos estão sendo direcionados no sentido de dar condições necessárias para que as localidades possam suportar e atender a demanda turística. Um destino turístico deve oferecer primeiramente boa condição de vida aos moradores e depois para os turistas, tomando precauções para não haver divulgação excessiva de locais antes destes estarem estruturados e organizados adequadamente para comportar o exercício da atividade turística.

A Barra do Ribeira foi contemplada pelos dois projetos em diferentes ações. Pelo projeto da SOS Mata Atlântica, a Barra do Ribeira teve sua importância ressaltada através do Centro de Interpretações, difundida também através da educação ambiental. Porém como já mencionado não são todos os turistas que vão a Barra do Ribeira que têm a oportunidade de conhecer o Centro. Já pela Agenda do Ecoturismo, foi alcançada a capacitação de jovens que vivem na Barra do Ribeira, com o curso de formação de monitoria ambiental.

Por sua vez, as organizações formadas pela comunidade atuaram em projetos pequenos, mas de grande relevância, no que diz respeito à valorização da cultura 
caiçara e organização social, como por exemplo, a Associação dos Jovens da Juréia, que exerce um papel representativo na Barra do Ribeira, como se observa a seguir.

Em 1993 foi criada a Associação dos Jovens da Juréia (AJJ), entidade que surgiu da necessidade de organização da população caiçara contra a ameaça de expulsão dos moradores do local, após a criação da Estação Ecológica Juréia-Itatins. Como forma de incentivo para os moradores permanecerem na Juréia, a Associação passou a lutar pela criação de uma escola.

Com apoio da prefeitura, em 2000, a escola começou a funcionar, de maneira improvisada num Centro Espírita, com oito alunos da $1^{\text {a }}$ à $4^{\text {a }}$ série do ensino fundamental. Nela, os estudantes permaneciam durante quinze dias em regime de internato e voltavam para casa por cinco dias. De manhã, eles assistiam a aulas das disciplinas formais, enquanto à tarde, desenvolviam os saberes regionais em atividades práticas de roça, horta e pesca.

A AJJ estabeleceu parcerias com pesquisadores da Unicamp e USP. A sala de aula e a casa da professora foram construídas com o apoio do Núcleo de Apoio a Pesquisa sobre Populações Humanas e Áreas Úmidas (NUPAUB) da USP e as pesquisadoras em educação Alik Wunder da Unicamp e Luísa Alonso da Unesp colaboraram com a construção da proposta pedagógica da escola e com a formação dos professores ${ }^{22}$.

No início de 2003, o funcionamento da escola foi ameaçado, pois a Secretaria de Educação do município de Iguape estava empenhada em fechar a escola, que tinha na época somente dois alunos matriculados de $1^{\underline{a}}$ a $4^{\underline{a}}$ série. Depois de várias reuniões 0 prefeito manteve a escola aberta até o final de 2003. Houve uma mobilização dos apoiadores da escola e a comunidade para conseguir a implantação de uma sala de aula de $5^{\mathrm{a}}$ a $8^{\mathrm{a}}$ série, cuja demanda era de 12 alunos. Foi feito um plano pedagógico adaptado as necessidades da Escola Caiçara que depois de meses de análise na Secretaria Estadual de Educação não obteve aprovação devido ao número reduzido de alunos. A Secretaria deu a opção de implantação de uma Tele-Sala de Aula que

\footnotetext{
${ }^{22}$ Escola da Juréia propõe convivência entre a mata e a comunidade cultural. Disponível em: http:// www.cienciaecultura.bvs.br/pdf/cic/v55n3/a08v55n3.pdf Acesso em 14/03/2007
} 
funciona com um professor-monitor e o conteúdo das disciplinas é passado aos alunos através de vídeos e livros.

Ainda com o objetivo de contribuir para o estímulo da continuidade das tradições culturais caiçaras, foi implantado o Centro de Cultura Caiçara da Barra do Ribeira. A gestão do Centro é feita pela AJJ, sendo que este projeto foi selecionado em 2004, pelo Programa Cultura Viva do Ministério da Cultura, que tem o apoio da Petrobrás. Entre as atividades do Centro, são oferecidas oficinas de viola, rabeca, dança de fandango, construção de instrumentos e confecção de artesanato caiçara, além de apresentações de grupos de fandango e outras manifestações culturais da região. Além disso, há cursos extras de produção cultural e associativismo, onde a programação é gratuita e os cursos serão realizados até $2008 .^{23}$

Vale observar que em 1989, a caixeta; matéria prima utilizada para a confecção dos instrumentos do fandango; foi proibida de ser explorada, desestimulando a manutenção da cultura caiçara e provocando um grande desemprego em Iguape, sendo que as oito serrarias existentes que processavam a caixeta e a mandavam para as fábricas, eram responsáveis por 400 empregos diretos e indiretos.

Logo depois da proibição da exploração da caixeta, foi criada a Associação dos Caixeteiros de Iguape, com objetivo inicial de lutar pela legalização da atividade, onde ganhou o apoio de pesquisadores do departamento de Ciências Florestais da Esalq Escola Superior de Agricultura Luiz de Queiroz, de Piracicaba, SP, que começaram a estudar a situação ${ }^{24}$.

A partir da elaboração do Diagnóstico das Áreas de Caixeta, em parceria com a Associação dos Caixeteiros de Iguape e com o Núcleo de Populações em Áreas Úmidas do Brasil (NUPAUB) da USP, que recebeu financiamento de U\$10 mil da Fundação Ford, concluiu-se que o manejo sustentado da espécie tinha grande potencial econômico além de atender a uma necessidade social com as atividades relacionadas ao uso da madeira. As informações obtidas geraram um relatório, escrito pelo professor

\footnotetext{
${ }^{23}$ Caiçaras se tornam professores para resgatar tradição de sua comunidade. Disponível em: http://www.ruralnet.com.br/meioambiente/default.asp?noticia=1517. Acesso em 08 de fevereiro de 2007. ${ }^{24}$ Globo Rural: Caixeta. Disponível em:
} http://globorural.globo.com/barra.asp?d=/edic/173/fichaplanta1.htm. Acesso em: 15 de maio de 2007. 
Virgílio Maurício Viana, da Esalq, que subsidiou uma nova legislação, em vigor desde 1992, legalizando a atividade e estabelecendo normas para o manejo sustentado da caixeta.

Assim, em 1995 foi instalada a Serraria da Associação dos Jovens da Juréia, que resultou de um projeto desenvolvido em uma parceria entre a AJJ, a Rede Brasileira de Agroflorestas e o Programa da Terra (PROTER). (NOLASCO\&VIANA:2004:4).

Dessa forma, o Centro de Cultura Caiçara da Barra do Ribeira pôde exercer suas atividades de confecção de instrumentos e de artesanato caiçara que utilizam a caixeta, devido a existência da Serraria formada pela Associação.

Vale ressaltar que a formação da Associação dos Monitores Ambientais de Iguape (AMAl) é uma parceria estabelecida com a Associação dos Jovens da Juréia, que representa assim uma organização social de extrema importância para a Barra do Ribeira, no sentido de proporcionar melhores condições de vida e de manutenção da cultura caiçara. A AMAI tem como principais objetivos (AMAI: 2001):

- Promover o desenvolvimento econômico da região através do trabalho de manejo sustentável dos recursos naturais e do ecoturismo;

- Estimular ações e desenvolver atividades de Educação Ambiental que visem à melhoria da qualidade de vida da comunidade local;

- Fomentar a valorização e manutenção da cultura tradicional da região;

- Promover a realização de conferências, palestras, movimentos, cursos e seminários voltados, em especial, à área de educação ambiental

- Elaborar e desenvolver projetos socioambientais.

A AMAI promovia atividades sócio-educativas, palestras, encontros, cursos, junto à população da Barra do Ribeira, como o projeto Criança Natureza: Um Futuro Promissor, voltado ao trabalho de educação ambiental em duas escolas estaduais do município, com palestras, discussões de vídeos, oficinas de papel reciclado, plantio de mudas nativas, debates e atividades na Praia da Juréia, como campeonato de surf e despoluição de praia e também desenvolvia roteiros de interpretação ambiental levando 
os alunos ao conhecimento "in loco" do meio em que vivem. Essas atividades também eram oferecidas aos visitantes na alta temporada, principalmente em janeiro.

Segundo o Manifesto $\mathrm{AMAl}^{25}$, desde de janeiro de 2001, a organização em parceria com o Instituto Florestal desenvolvia trabalhos no Núcleo Praia da Juréia da Estação Ecológica Juréia-Itatins, orientando visitantes no Costão da Juréia e Cachoeira do Pocinho e monitorando grupos na Trilha do Imperador (num percurso de 1.643 metros de distância) onde até então não havia nenhum trabalho de educação ambiental ou ordenamento da visitação. De acordo com a AMAI, o trabalho trouxe valiosos resultados como a coibição da entrada de clandestinos pelo costão rochoso, a diminuição do impacto do lixo no núcleo (com a instalação de três pontos de coleta seletiva, abordagem dos visitantes sobre a questão do lixo e realização de multirões de despoluição de praia), controle da entrada de resíduos poluentes e animais domésticos na Cachoeira do Pocinho, esclarecimento dos visitantes sobre as características e comportamentos necessários em uma unidade de conservação. $O$ trabalho proporcionou também um maior conhecimento dos atrativos naturais e a diminuição da insistência dos visitantes para entrar na EEJI sem autorização como acontecia anteriormente.

Porém, em março de 2003, a AMAl; que realizava os passeios com objetivo educacional e arrecadava cinco reais por pessoa, de forma a controlar a limpeza na Praia da Juréia; foi proibida pela Direção da Estação Ecológica, após a denúncia da Associação Eco Juréia (AEJ), de prosseguir com o monitoramento de grupos na Trilha do Imperador, interrompendo o trabalho que vinha desenvolvendo há dois anos. $A$ Trilha foi fechada, pois se encontra dentro da EEJI, sendo que o argumento utilizado para o fechamento da trilha era de que não estava atendendo ao fim educacional de uma Estação Ecológica, degradando o local.

O fechamento da trilha foi objeto de polêmica, pois a passagem pela trilha era realizada por uma instituição capacitada com formação em monitoria ambiental e

\footnotetext{
${ }^{25}$ Manifesto AMAI. Disponível em: http://www.ruralnet.com.br/meioambiente/default.asp?noticia=1523. Acesso em 06 de janeiro 2007.
} 
autorização prévia do diretor da Estação. Em uma entrevista à Agência Estado ${ }^{26}$, afirma que a visitação monitorada, em algumas áreas atende ao objetivo de pesquisa e educação ambiental da reserva. Segundo Luiz Roberto Numa Oliveira, diretor de Reservas e Parques Estaduais do Instituto Florestal, a experiência com a AMAl foi bem sucedida, por manter a função da Trilha dentro da unidade e por oferecer alternativa para a comunidade de moradores e deveria ser retomada depois das obras e da normatização, o que acabou não ocorrendo.

O debate em torno desta questão, envolveu a Associação Eco Juréia, a AMAI, o Instituto Ing- Ong e o Grupo de Intervenções e Educação Ambiental; que é formado por pesquisadores da Universidade de São Paulo ( USP) e da Universidade de Campinas (UNICAMP). De um lado, a Associação Eco Juréia que denunciou esta atividade, classificando-a como ilegal, e de outro lado os defensores da atividade, que consideram a atuação da AMAI uma ferramenta de inclusão social das comunidades na realidade da conservação ambiental.

Segundo a argumentação apresentada pelo Instituto Ing - Ong, o Sistema Nacional de Unidades de Conservação, permite a visitação pública em Estações Ecológicas com objetivo educacional, e não necessariamente a visitação de escolas. A Estação Ecológica Juréia-Itatins dispõe de uma portaria (Diretor Geral de 23-7-99) que define as normas para desenvolvimento de trabalhos de educação ambiental para grupos organizados, na qual "as visitas só serão permitidas com o acompanhamento de Monitor Ambiental (um monitor para no máximo cada vinte visitantes) formado por curso com base na Resolução SMA/SP-32, de 31/03/98". Portanto, os monitores ambientais da AMAI estão legalmente amparados para o exercício da atividade de monitoria ambiental na EEJI ${ }^{27}$.

Esta questão merece atenção especial, pois o processo de desenvolvimento do turismo na Barra do Ribeira foi prejudicado por esta polêmica. As duas entidades atuam

\footnotetext{
${ }^{26}$ Agência Estado. 09/04/2003. Disponível em: http://www.agenciaestado.com.br. Acesso em: 15 de janeiro de 2007

${ }^{27}$ Esclarecimento a Rede CTA - JMA do Instituto Ing-Ong e da AMAl. Disponível em: http://www.ruralnet.com.br/meioambiente/default.asp?noticia=1552. Acesso em: 07 de fevereiro de 2007.
} 
com o mesmo objetivo, o de preservar a Estação Ecológica Juréia- Itatins e seu entorno, porém a falta de entendimento entre elas, cria uma barreira para atingir os objetivos propostos por ambas as entidades.

A Associação Eco Juréia (AEJ) é uma Organização da Sociedade Civil de Interesse Público (OSCIP), criada em 2000 e tem como objetivo: preservar os rios, o mangue, a flora e a fauna da Juréia, com desenvolvimento sustentável; defender as populações caiçaras e desenvolver projetos de educação ambiental, como recurso indispensável à formação da cidadania, assim como todo o tipo de projeto que traga benefícios à sociedade e ao meio ambiente; divulgar informações, realizar cursos e palestras, estimular pesquisas, programar ações e eventos que instrumentalizem os seus objetivos. $^{28}$

A AEJ atua basicamente em educação ambiental, com a realização de palestras para a população da Barra do Ribeira e divulgando informações sobre o local, no sentido de denunciar as questões principais da Barra do Ribeira, como a coleta de lixo e outras irregularidades identificadas no local, através da publicação de um jornal trimestral.

A AEJ compreende o turismo como uma fonte que pode alavancar o progresso na Barra do Ribeira, porém a visão da Organização é reticente em relação ao turismo dentro do Morro da Juréia, pois na Barra do Ribeira há incidência do turismo de um dia, que na opinião da instituição é prejudicial ao local, pois não possui infra-estrutura turística, temendo que além de degradar a Barra do Ribeira, possa ter conseqüências para a EEJI.

Verifica-se que houve uma falta de diálogo entre a AEJ e a AMAI, sobre a questão do turismo no Morro da Juréia, resultando na paralisação das atividades da AMAI. No artigo em que a AEJ denuncia a atividade ilegal, há um apontamento sobre a questão do turismo, onde a AEJ afirma que na Barra do Ribeira há trilhas para serem exploradas, onde o turismo sustentável pode se expandir, porém advertiu para o turismo dentro da Estação Ecológica.

\footnotetext{
${ }^{28}$ Associação Eco Juréia. Disponível em: http://www.ecojureia.org.br . Acesso em: 08 de janeiro de
} 2007. 
Esta denúncia deixou a AMAI temerosa em prosseguir como monitoramento ambiental, onde aguardou por três anos a liberação da trilha, e tentou formas de contornar a situação, de forma a regularizar a atividade. A AMAI havia criado em 2001, um Posto de Informações Turísticas na Barra do Ribeira ${ }^{29}$, que servia também como sede da Associação e como Centro de Pesquisa sobre assuntos ambientais para a escola local. Porém, por falta de recursos financeiros para aquisição de equipamentos para desenvolver atividades esportivas; equipamentos para locomoção dos visitantes; aquisição de material de divulgação para turistas e também o fato do fechamento da Trilha do Imperador, o Posto foi fechado e as atividades da AMAI foram paralisadas.

Com a alteração da EEJI em um mosaico de unidades de conservação e com a criação do Parque Estadual do Prelado, espera -se que haja um acordo entre as duas organizações para que sejam estabelecidas condições necessárias e adequadas para desenvolver o turismo na Barra do Ribeira, podendo proporcionar benefícios tanto para a comunidade que dependia desta atividade, quanto para os turistas.

${ }^{29}$ Dossiê AMAl.AMAl.2001 


\section{CAPÍTULO 3: Barra do Ribeira e seu potencial turístico}

Nos capítulos anteriores foi discutida a importância de um planejamento turístico e da prática de um turismo sustentável para que haja benefícios para a população local, onde projetos e iniciativas de todas as esferas possam gerar novas alternativas de sustento, particularmente para a Barra do Ribeira. Neste capítulo será abordado a situação da Barra do Ribeira, suas deficiências, assim como seus atrativos e de que forma a população compreende o turismo.

Há duas grandes questões incidentes sobre a Barra do Ribeira. Uma delas é que a localidade é vista apenas como mais um atrativo do município de Iguape, onde a distância com o centro da cidade influi muito no desenvolvimento do local. Com a dificuldade de acesso e comunicação, a Barra do Ribeira se encontra isolada e esquecida por gestores do município.Outro fator apontado é a sua proximidade com a Estação Ecológica, local de muitos conflitos sociais, dificultando a possibilidade de melhorias da infra-estrutura devido as suas implicações legais, representando assim um ambiente intocável e que não pode ser alterado.

O descaso por parte do município de Iguape com a Barra do Ribeira é notado já no Departamento de Turismo de lguape, onde não é possível obter maiores informações sobre a Barra do Ribeira. Há poucos folhetos de pousadas e no folheto de atrativos de Iguape, a Barra do Ribeira, conhecida como praia da Juréia está assim citada:

"Localizada a $18 \mathrm{~km}$ do centro de Iguape. É uma das mais belas praias do litoral paulista. A sua comunidade, formada por pescadores, ainda mantém raízes caiçaras".

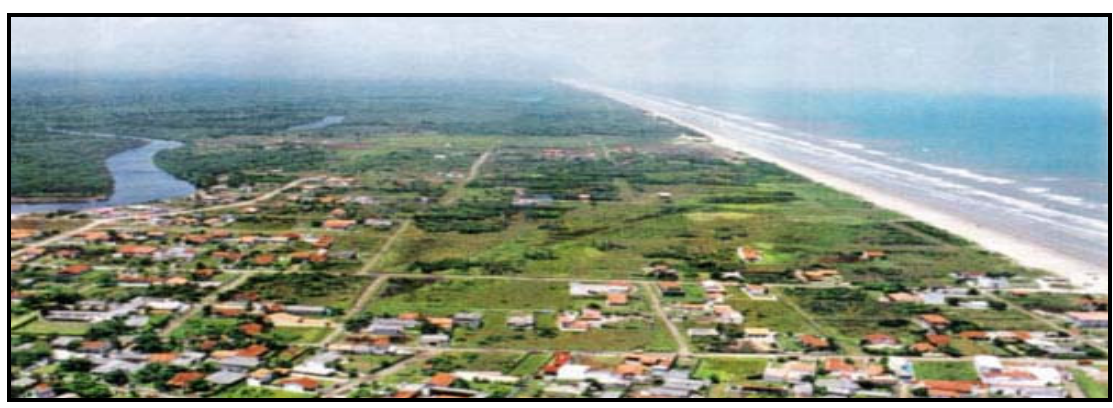


Foto 1: Vista parcial da Barra do Ribeira. Fonte: Associação Eco Juréia

Vale ressaltar que o município de Iguape foi transformado em Estância Balneária através da Lei no 163 de 27 de setembro de 1948, onde a condição de estância balneária de Iguape esteve calcada nas praias de llha Comprida, sendo que em 1995, a Lei no 9072 transformou Ilha Comprida em Estância Balneária. Sendo assim, a única praia que justifica o fato do Município de Iguape permanecer como Estância Balneária, encontra-se na Barra do Ribeira, a Praia da Juréia. O abandono por parte da Prefeitura de Iguape é evidenciado por Silva ${ }^{30}$, principalmente no que se refere ao repasse de verbas para asfaltar a estrada de terra. De acordo com o assessor de Turismo, a população da Barra do Ribeira desconhece a existência de um Fundo de Melhorias das Estâncias que se destina ao desenvolvimento de programas de urbanização, melhoria e preservação ambiental e melhoria de qualidade de desenvolvimento municipal das estâncias. Inclusive, no período de 1996 a 2003, foram repassadas verbas de cerca de $\mathrm{R} \$ 4,2$ milhões para cada Estância, incluindo o município de Iguape, onde somente essa verba daria para asfaltar quatro vezes a estrada de terra da Barra do Ribeira ${ }^{31}$.

Os esforços de outras esferas governamentais não são efetivos sem a atuação do município de Iguape. Perante tal descaso já foi discutida a emancipação da Barra do Ribeira, para que a falta de comunicação com a Prefeitura, e também a distância não sejam empecilhos para o desenvolvimento do local. A Barra do Ribeira possui cerca de três mil moradores fixos e cinco mil sazonais, sendo contabilizados 200 eleitores. ${ }^{32} \mathrm{De}$ acordo, com a Associação Eco Juréia, as sucessivas administrações da Prefeitura Municipal de Iguape se caracterizam pelo abandono com que tratam a Barra do Ribeira, que não conta com um Plano Diretor.

\footnotetext{
${ }^{30}$ PT Assembléia Permanente. Disponível em: http://ptalesp.locaweb.com.br/CN02/desmonte/nots det.asp?id=347. Acesso em: 16 fev 2007

${ }^{32}$ Barra do Ribeira: Município da Juréia?Jornal da Juréia. Ano V, oํ19, jan-fev-mar 2005.
} 
Ainda segundo a AEJ, a Prefeitura de Iguape arrecada com o imposto do ICMS ecológico, dois milhões e seiscentos mil reais, sendo oriundo da Estação Ecológica Juréia- Itatins, porém esta verba não é repassada para a Barra do Ribeira. ${ }^{33}$

Em 15 de junho de 2002 a Associação Eco Juréia aplicou um formulário durante a Ação Cidadania ${ }^{34}$ promovida pela rádio Juréia FM, onde foram entrevistadas 42 pessoas, pois de acordo com a Associação, durante três horas de trabalho foi verificado pelo grupo que as respostas eram sempre as mesmas e que a partir daí poderia ser feito um diagnóstico.

O formulário apresentou as seguintes perguntas: nome, profissão, idade, estado civil, escolaridade, renda familiar, quanto tempo mora no local, quantos filhos, se tem casa própria, qual o destino dado ao lixo, porém a principal pergunta foi qual o maior problema que encontram na Barra do Ribeira e o que é preciso fazer para melhorá-lo. Foi perguntada também qual era opinião a respeito do turismo.

Em relação aos problemas da comunidade foram obtidas 88 respostas e em relação às opiniões sobre turismo foram 50 respostas.

\section{TABELA 4: PROBLEMAS NA BARRA DO RIBEIRA}

\section{(Associação Eco Juréia,2002)}

\begin{tabular}{|c|c|c|c|c|c|c|c|c|c|c|c|c|c|c|c|c|c|}
\hline Problemas & & & & & & & & & & & & & & & & Qtd & Total \\
\hline $\begin{array}{l}\text { Asfaltamento da } \\
\text { estrada }\end{array}$ & 1 & 1 & 1 & 1 & 1 & 1 & 1 & 1 & 1 & 1 & 1 & 1 & 1 & 1 & 1 & 15 & $17,05 \%$ \\
\hline Desemprego & 1 & 1 & 1 & 1 & 1 & 1 & 1 & 1 & 1 & 1 & 1 & 1 & 1 & & & 13 & $14,77 \%$ \\
\hline Saúde Pública & 1 & 1 & 1 & 1 & 1 & 1 & 1 & 1 & 1 & 1 & 1 & 1 & 1 & & & 13 & $14,77 \%$ \\
\hline $\begin{array}{l}\text { Mudança na } \\
\text { política local }\end{array}$ & 1 & 1 & 1 & 1 & 1 & 1 & 1 & 1 & & & & & & & & 8 & $9,09 \%$ \\
\hline $\begin{array}{ll}\text { Muro } & \text { de } \\
\text { contenção } & \end{array}$ & 1 & 1 & 1 & 1 & 1 & 1 & & & & & & & & & & 6 & $6,82 \%$ \\
\hline Infraestrutura & 1 & 1 & 1 & 1 & 1 & 1 & & & & & & & & & & 6 & $6,82 \%$ \\
\hline
\end{tabular}

\footnotetext{
33 idem
}

${ }^{34}$ A Ação prestou serviços gratuitos para a comunidade como: assistência média, odontológica, advogados, emissão de documentos, corte de cabelos, palestras e gincanas. 


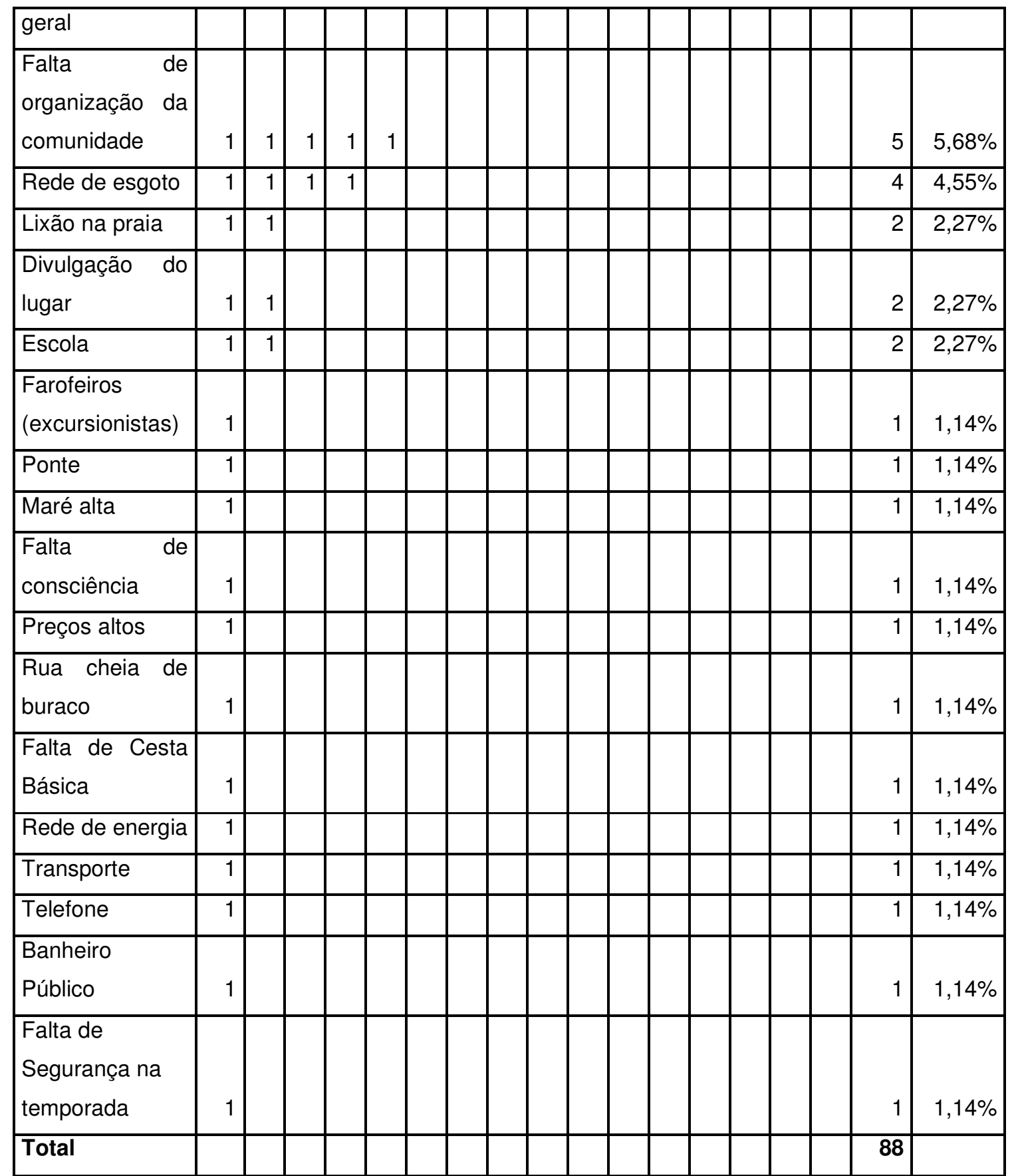

Fonte: Associação Eco Juréia, 2002.

Através da tabela, pode-se constatar que a maior porcentagem de problemas detectados pela comunidade para o melhor desenvolvimento da mesma é o asfaltamento da estrada com $17,05 \%$ do total de 42 entrevistados. No gráfico 2 a seguir,nota-se que $26 \%$ dos entrevistado acham o turismo "bom" enquanto que $16 \%$ mencionaram a falta de infra-estrutura. 


\section{GRÁFICO 2: OPINIÃO SOBRE O TURISMO}

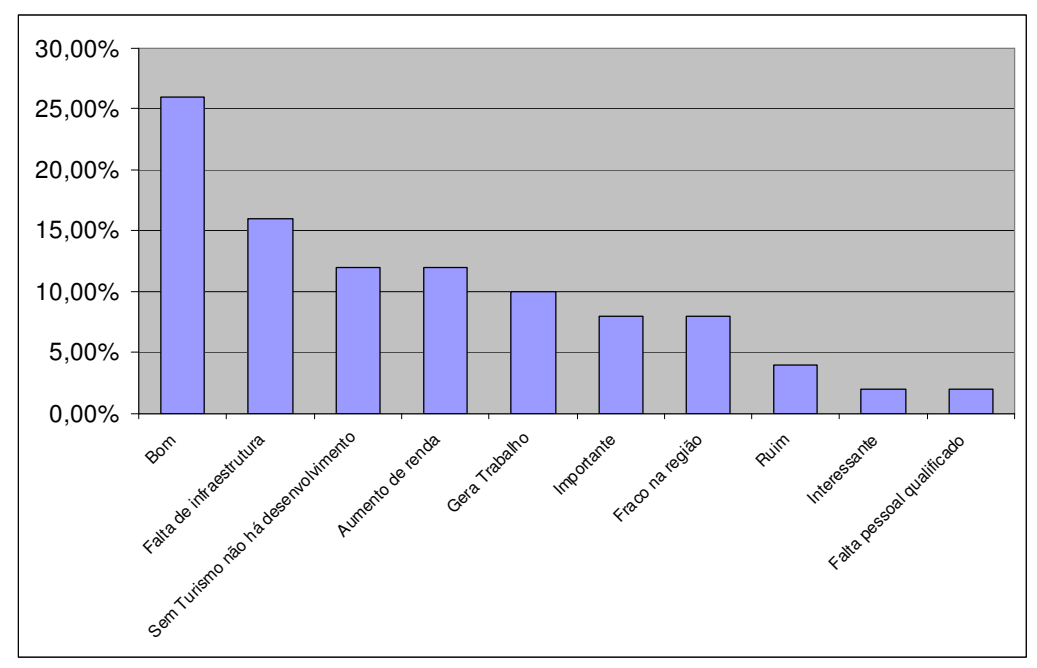

Fonte: Associação Eco Juréia, 2002.

No entanto, o asfaltamento da estrada que liga o centro de Iguape à Barra do Ribeira, apesar de ser um obstáculo para os turistas, ainda é uma forma de preservar o local. Caso haja reais intenções de asfaltar a estrada, antes seria necessário que fosse realizada uma melhoria na infra-estrutura da Barra do Ribeira, para poder suportar a aumento do fluxo de turistas que seria ocasionado com o asfaltamento da estrada.

Já na Barra do Ribeira, só a via principal é asfaltada, e o resto das ruas são de areia. Este tipo de questão gera contradições, pois o asfaltamento poderia descaracterizar o local, incidindo em uma indagação: modificar os lugares para agradar os turistas, ou mostrar ao visitante as coisas genuínas locais ${ }^{35}$. Em períodos de chuva há muitos transtornos para a locomoção, as ruas ficam inundadas e também ocorrem muitas enchentes. Portanto é necessário um trabalho de escoamento das águas pluviais.

Um dos problemas identificado pela comunidade é o do "farofeiro", ou seja, o turista de um dia. Segundo Queiroz (2001:29), no litoral sul de São Paulo predomina o

\footnotetext{
${ }^{35}$ Micro-Redes de Turismo de Base Comunitária: A Experiência do V Fórum Social Mundial. Disponível em: http://www.ecoviagem.com.br/ecoviagens/ecoreporter interna.asp?codigo=9882. Acesso em: 27 de março de 2007.
} 
turismo de segunda residência ou senão de excursionistas, onde a permanência na área é curta, passando menos que 24 horas. Estes turistas não usam nenhum tipo de hospedagem, trazem sua própria alimentação, usam transporte coletivo e não gastam nada, degradando bastante o local. Na Barra do Ribeira não há infra-estrutura para receber este tipo de turismo, sendo que só tende piorar a situação local, provocando brigas com os nativos do Bairro e acumulando lixo no local. Uma medida que foi adotada para amenizar o impacto advindo do turismo de um dia, foi a proibição da travessia dos ônibus de excursão pela balsa. De acordo com a diretora da Eco Juréia, Cybele Silva, a maioria destes turistas vêem da periferia de São Paulo, onde há anúncios sobre excursões para a Barra do Ribeira, cobrando- se 20 reais por pessoa.

Outros problemas identificados no Diagnóstico realizado pela EcoJuréia, com $14,17 \%$, foram o desemprego e a saúde pública. Conforme entrevista realizada em janeiro de 2007 na Barra do Ribeira com moradores, líderes comunitários e comerciantes, verifica-se que a maioria deles reconhece a importância do turismo para a Barra do Ribeira. No entanto, o envolvimento da comunidade é insuficiente na questão da atividade turística, pois muitos se sentem acuados, pois não se consideram aptos e capazes para mobilizar mudanças neste sentido. São poucos os moradores que se beneficiam desta atividade, ou seja, aqueles que possuem residência própria, que as disponibilizam para aluguel em temporadas ou aqueles que prestam serviços de caseiros. O resto das atividades ligadas ao turismo, pouco contam com mão- de - obra da população local, pois os comerciantes são pessoas de fora e contam com a ajuda de familiares para execução das atividades. Observa-se que a maioria dos empregos oriundos da atividade turística são temporários, como por exemplo, o emprego de salvavidas. Todos os anos, os jovens têm que prestar provas de aptidão para conseguir o posto de salva-vidas, sendo que a efetivação no emprego não é garantida.

A qualidade dos serviços prestados pelos poucos moradores que participam da atividade turística é considerada precária, de acordo com o levantamento da opinião dos turistas. Apesar da pouca participação local na atividade turística, o desenvolvimento do turismo na região é visto como solução para o desemprego, onde é reivindicada a melhoria na infra-estrutura e que o turismo seja mais organizado e realizado com controle. 
Quanto à saúde pública foi muito reclamada a falta de médico, que aparece no local apenas uma vez por semana, não há medicamentos suficientes para suprir as necessidades da comunidade, há apenas uma ambulância e em estado precário, não conseguindo atender a demanda da população. Já ocorreram casos de mulheres grávidas que entraram em trabalho de parto e não havendo tempo de chegar ao Hospital de Iguape deram a luz na balsa, mostrando a precariedade do sistema de saúde local.

$\mathrm{Na}$ pesquisa realizada em janeiro de 2007, percebe-se que muitos moradores e comerciantes possuem consciência ecológica, mas não tomam atitudes, pois esperam políticas do Governo Municipal como solucionadoras dos problemas. A educação ambiental foi bastante difundida na região, apoiada por programas da Universidade de São Paulo, como a Escola Caiçara e o projeto realizado pela AMAI nas duas escolas públicas da região. Porém, o que é mais necessário é a educação ambiental para os turistas, pois a maiorias deles não têm conhecimento sobre a importância do local, sendo que após a paralisação das atividades da AMAI, não têm sido feito nada nesse sentido.

O bairro possui algumas lixeiras espalhadas pela via principal, mas não há lixeiras na praia, onde não é realizada nenhuma limpeza. A coleta de lixo é ineficiente, sendo que na última temporada, o lixo permaneceu durante quase um mês sem ser recolhido. O rumor sobre esta questão foi de que apenas eram recolhidos os lixos das casas que estavam com o IPTU quitado.

Assim, relacionados aos problemas como educação ambiental para turistas e o lixo, pela primeira vez ocorreu a Campanha Verão Limpo na Praia da Juréia, nos dias 11 e 12 de janeiro de 2007, sendo que esta campanha ocorre sempre no período de dezembro a janeiro em todo o litoral paulista. A campanha realizada pela Secretaria do Meio Ambiente do Estado de São Paulo (SMA) em parceria com a Companhia de Tecnologia de Saneamento Ambiental (CETESB), teve também atividades de educação 
ambiental, onde segundo os dados da $\mathrm{SMA}^{36}$ participaram cerca de 1,5 mil banhistas. Foram executadas pela campanha atividades como:

- Oficina Cartilha de Atividades: com mensagens educativas e figuras para colorir;

- Arena de Escultura: atividades de esculturas na areia, focando a limpeza da areia, praia e mar;

-Apresentação do Laboratório Móvel de Monitoramento de Qualidade de Águas.

A Campanha Verão Limpo 2007 teve patrocínio da COMGÁS Natural, Porto Seguro e Companhia Brasileira de Alumínio, e apoio da Polícia Militar, PARAMOUNT, DER, DERSA, ECOVIAS e ARTESP, além da prefeitura municipal de lguape, e foram distribuídas à população sacolinhas plásticas para lixo e a "Cartilha sobre Balneabilidade", contendo informações sobre o trabalho de monitoramento da CETESB nas praias paulistas. Segundo técnicos da CETESB presentes no local, a água do mar foi considerada uma das mais puras da região.

\subsection{Atrativos Turísticos: Naturais e Culturais}

Após serem abordados os principais problemas do desenvolvimento do turismo na Barra do Ribeira serão apontados seus principais atrativos. O perfil do turista da Barra do Ribeira, segundo o monitor ambiental Tapico ${ }^{37}$, é de famílias de São Paulo que conhecem o local através de indicação de amigos e também dos veranistas, onde o ambiente pacato e tranqüilo é um dos atrativos.

A localização da Barra do Ribeira em uma foz representa um diferencial para o lugar, comparando com outras praias do litoral paulista. O turista pode optar por praticar suas atividades tanto na praia como nos dois rios da região, o Ribeira e o Suamirim.

Há uma pequena área no Rio Ribeira, denominada Portinho, utilizada como "praia" devido à pequena concentração de areia na margem; com pouca infra-estrutura,

\footnotetext{
${ }^{36}$ Campanha Verão Limpo atrai 3,5 mil pessoas em Iguape e Ilha Comprida. Secretária do Meio Ambiente- Notícias. Disponível em: http://www.ambiente.sp.gov.br/destaque/2007/01/16 verao.htm. Acesso em: 15 janeiro de 2007

${ }^{37}$ Entrevista no Departamento de Turismo de Iguape com Tapico, monitor da AMAI no dia 11/01/2007.
} 
contando com um pequeno bar e um mini deque. No local não há sanitários e muito menos lixeira. Na foto 4 pode-se ver o acúmulo de lixo na margem do rio.

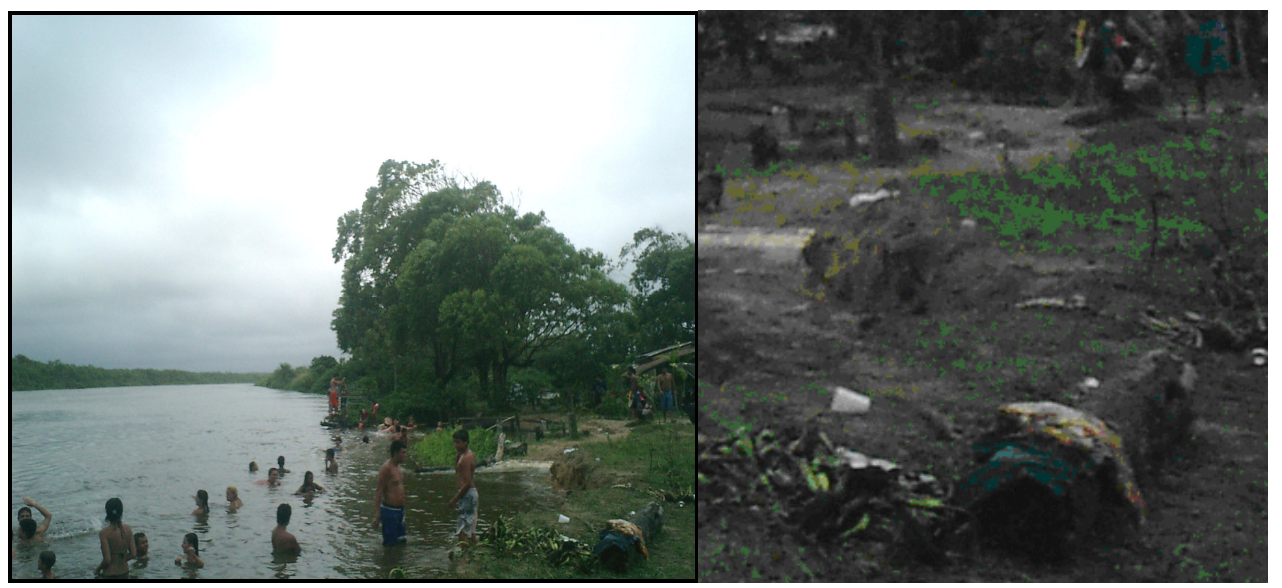

Foto 2: Portinho do Rio Ribeira. Foto: Fabianne Ykemoto, pesquisa de campo realizada em 25 de fevereiro de 2007.

No Rio Ribeira são realizadas atividades como pesca e passeios de barco e caiaque, sendo que perto do centro pode-se alugar estes equipamentos pelo preço de 5 a 10 reais. O Portinho fica um pouco distante do Centro, impedindo que fique super lotado, sendo que as pessoas que freqüentam o local costumam ir de carro. O Rio Suamirim por sua vez oferece uma trilha ecológica, a Vila Alegria, uma trilha histórica mantida pela comunidade. O trajeto começa com a travessia do Rio e o turista caminha sobre o mangue em uma passarela de madeira de 525 metros, ao todo são 1500 metros de trilha ${ }^{38}$.

Já o tour de barco tem dois roteiros: a apreciação do encontro do Rio Ribeira de Iguape com o mar ou visitar as encostas do Rio Suamirim e conhecer a flora e fauna de Iguape. Os passeios duram 40 minutos e custam $R \$ 45$.

A Praia da Juréia é o principal atrativo do local, com mais de $18 \mathrm{~km}$ de extensão, que por um lado pode se chegar ao Costão da Juréia e de outro está localizada a foz do Rio Ribeira. A Praia também possui pouca infra-estrutura, com dois quiosques principais e o Corpo de Bombeiros, sendo que o restante da praia não tem ocupação, pois depende de aprovação de licenciamento para novos estabelecimentos. Na praia

\footnotetext{
${ }^{38}$ CD Ecoturismo na Mata Atlântica : Um Guia Interativo sobre o Vale do Ribeira.
} 
são realizadas atividades como a pesca e o surfe, onde com certa freqüência são realizados campeonatos de surfe, que atraem surfistas das regiões mais próximas.

No Costão há também a Trilha do Imperador, que ficou conhecida por ter servido de passagem de informações entre a sede do Império e outras regiões do país quando da inauguração da linha telegráfica entre Santos e Iguape.

Como atrativos culturais podemos citar a cultura caiçara que tem como principal destaque o fandango e também algumas festividades do local. A cultura caiçara é, historicamente, fruto da miscigenação entre colonizadores portugueses, índios das regiões litorâneas e ex-escravos que, após a libertação, concentraram-se à beira-mar. Essas comunidades são formadas, até hoje, em grande parte por pescadores e artesãos que também têm um modo de vida intimamente ligado à pequena agricultura e ao extrativismo. Esses povos foram, ao longo do tempo, adquirindo conhecimento aprofundado acerca do ambiente em que viviam e acumularam um repertório cultural da maior riqueza. São danças, músicas, costumes e vocabulário com inúmeras palavras de uso local, entre outras manifestações.

O fandango é uma manifestação caiçara que reúne dança e música e está associada ao trabalho na lavoura e na pesca, envolvendo instrumentos artesanais, como a viola e a rabeca fabricados artesanalmente com a madeira da caixeta.

Os fandangos eram oferecidos como pagamento aos mutirões de lavoura no plantio e colheita, sendo que o beneficiado pelo trabalho realizado oferecia aos participantes farta comida e um fandango que atravessava a noite. Os fandangos aconteciam também em festas religiosas, no carnaval ou pelo simples divertimento. $A$ prática do fandango está também associada a outras manifestações culturais, algumas de caráter religioso como o terço cantado, as reiadas ou folias de reis e as bandeiras, que saem em romaria pelos municípios. Porém, este atrativo ainda é pouco difundido no local, são poucos os turistas que têm conhecimento da cultura caiçara e não estão sendo realizadas apresentações de fandango, abrindo espaço para outros tipos de manifestações populares mais conhecidas pelos turistas, como o Carnaval.

O Carnaval da Barra do Ribeira é bem simples, contando com um trio elétrico e poucas alas. A concentração para o desfile começa no centro da cidade e percorre um trajeto que vai até a praia. No samba enredo são cantadas e ressaltadas as belezas do 
local e utilizados termos como: reserva natural e união. Outra festividade do local é a Festa do Robalo, que não tem data fixa, mas acontece geralmente entre os meses de setembro e outubro, onde é apreciado o peixe robalo.

\section{2:Infra - estrutura turística}

Em janeiro de 2007 foi realizado um breve levantamento dos meios de hospedagem e serviços de apoio, evidenciando que a maioria dos estabelecimentos estão instalados no centro do bairro ou próximos à ele.

Mesmo a Barra do Ribeira sendo predominantemente um destino turístico de segunda residência, nos últimos anos vêm aumentando o número de pousadas no local, comparando-se com dados verificados a partir de visitas realizadas ao local em 1997, como pode ser verificado a seguir. Há também disponíveis casas para aluguel e quartos em casa de moradores e também um único camping perto da praia. A partir de um levantamento realizado em sites de busca na Internet e visitas ao local foram identificados os seguintes estabelecimentos:

\section{Quadro 2 : MEIO DE HOSPEDAGEM NA BARRA DO RIBEIRA}

\begin{tabular}{|l|l|}
\hline \multicolumn{1}{|c|}{1997} & \multicolumn{1}{|c|}{2007} \\
\hline Hotel Recanto da Juréia & Pousada dos Coqueiros \\
\hline Pousada Solar da Barra & Pousada Praia da Juréia \\
\hline Pousada Ecológica & Pousada Recanto da Juréia \\
\hline & Pousada Ecológica \\
\hline & Pousada Ísis \\
\hline & Pousada Solar da Barra \\
\hline & Restaurante e Pousada Aconchego \\
\hline & Pousada Portal da Juréia \\
\hline & Pousada Morada do Sol \\
\hline & Camping do Mélico \\
\hline
\end{tabular}

Fonte: Fabianne Ykemoto, pesquisa de campo realizada em 11 de janeiro de 2007. 
O comércio do local também tem crescido nos últimos anos. A Barra do Ribeira conta com três mercados bem equipados, porém foi notado que a maioria dos turistas que vão passar a temporada costumam levar a alimentação da cidade de origem ou compram em lguape ${ }^{39}$. Também existem dez lojas de roupas e acessórios, além de duas lojas de artesanato. Durante o fim de semana e no período de férias há uma feira informal com diversas variedades de artesanatos.

Os poucos restaurantes que existem, se concentram na rua que vai do centro á praia, sendo que os outros estabelecimentos são poucos freqüentados, pois a maioria das hospedagens é equipada com cozinha. Também existem vários bares que servem refeições, sendo outra opção para a alimentação.

No local há pouca sinalização, somente no início da Balsa e em alguns pontos da via principal existem placas informativas, como pode ser verificado na foto a seguir:

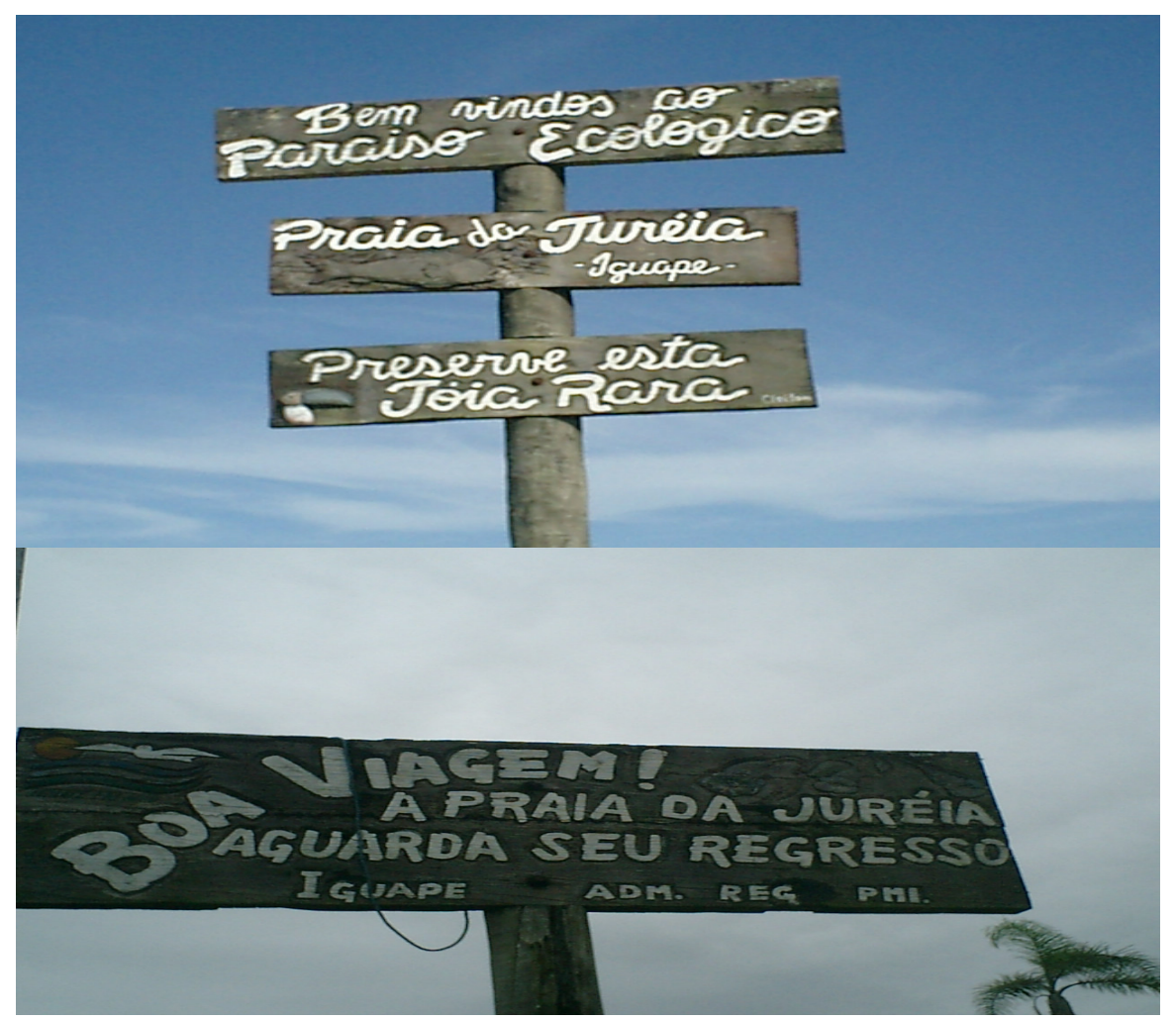

Foto 3: Sinalização. Foto: Fabianne Ykemoto, pesquisa de campo, 13 de janeiro de 2007.

39 Jornal da Juréia. Aniversário de 5 anos da Associação Eco Juréia.2006 Disponível em: http://www.ecojureia.org.br. Acesso em 08 de janeiro de 2007. 


\section{Considerações Finais}

Ao final deste trabalho pode-se fazer algumas considerações sobre o turismo na Barra do Ribeira, assim como sugestões para que esta atividade seja realizada de forma organizada.

Este trabalho abordou como o planejamento da atividade turística é importante para que esta seja considerada sustentável, ou seja, capaz de gerar benefícios para a população local com o mínimo de impacto ambiental.

O contraste entre a conservação ambiental da região do vale do Ribeira e os baixos índices de desenvolvimento humano na região chamou a atenção para o local, de forma a levantar debates sobre as melhores alternativas para o desenvolvimento local. O turismo foi considerado como solução para a geração de renda e proporcionar melhorias na qualidade de vida. Assim, foram direcionadas políticas públicas para operacionalizar a atividade turística na região, de forma a atender às necessidades dos municípios através da participação de todas as esferas envolvidas, principalmente a da comunidade local.

Foram realizadas pelas autoridades locais algumas ações que tiveram o objetivo de divulgar o potencial turístico da região, capacitar mão de obra e fazer educação ambiental. Porém a infra-estrutura básica e turística carecem de melhorias.

A Barra do Ribeira teve sua parcela de aproveitamento destas ações, porém seria necessário um melhor direcionamento de forma a se adaptar a realidade do local, pois a Barra do Ribeira se encontra no entorno de uma Estação Ecológica e recentemente de um Parque Estadual. Durantes muitos anos, a população da Barra do Ribeira esteve envolvida no esforço de modificar as condições impostas pela criação da EEJI, que impossibilitou a execução de atividades de subsistência, sendo criadas Associações para reivindicar seja o reassentamento dos moradores ou a devida indenização.

A proximidade com a Estação Ecológica e suas implicações legais dificultaram o desenvolvimento do local, somado ainda ao descaso por parte da administração pública 
local; ocasionado pela falta de apoio político e também pela falta de continuidade nas gestões públicas. A distância provoca um isolamento do bairro, além de uma sensação de abandono devido aos inúmeros problemas identificados, como a infra-estrutura precária. Apesar disso, por ser um local pacato e com características peculiares vêm crescendo o número de turistas que freqüentam a região.

O turismo na Barra do Ribeira é um tanto quanto incipiente, pois é pouco organizado, requisitando dessa forma, medidas adequadas e uma maior organização popular para execução desta atividade. Nota-se um certo índice de envolvimento da população na atividade turística, porém os moradores apresentam certa resistência a esta atividade, devido a fatores como a descrença nas políticas públicas, a péssima qualidade de vida, as limitações sofridas após a implantação da EEJI e principalmente porque muitos não foram beneficiados com o turismo.

Outro grande empecilho encontrado foi a falta de entendimento entre as organizações que atuam no local, dificultando o processo de desenvolvimento da atividade turística, como pode ser observado no caso da atuação da AMAl. Devido a este acontecimento, muitos moradores se opuseram à forma de atuação de organizações não governamentais, pois alguma delas, na opinião da comunidade, "boicotaram" a continuidade de atividades de monitoria e educação ambiental realizadas na Barra do Ribeira. Seria necessário criar um diálogo e uma interação entre as organizações atuantes na Barra do Ribeira, de forma a unir todos os envolvidos nas soluções para o local.

Em virtude da transformação de parte da EEJI em Parque Estadual e este estando localizado próximo à Barra do Ribeira, evidencia-se que é necessária a melhoria da infra-estrutura básica e turística da Barra do Ribeira para abrigar o aumento da demanda turística esperado pela criação do Parque, de forma a minimizar os prováveis impactos, controlando também 0 acesso ao local para não haver degradações futuras.

Existem diversos serviços de apoio ao Turismo, que podem ser uma alternativa para o desemprego na Barra do Ribeira, como, por exemplo, guias turísticos, garis, formação de cooperativas de coleta seletiva, entre outros; sendo que estes serviços 
oferecem vantagens por não estarem ligados diretamente à estabelecimentos comercials.

A criação do Parque Estadual também é uma boa oportunidade para empregar a comunidade local, principalmente no que refere à construção da infra-estrutura do parque e fiscalização, sendo que a Associação dos Monitores Ambientais de Iguape (AMAI) pode ser encarregada da condução dos visitantes e do monitoramento ambiental.

Verifica-se a necessidade de investimentos públicos para que haja melhoria na infra-estrutura básica de modo que o turismo seja próspero no local. A falta de recursos não pode se constituir como obstáculo para o desenvolvimento da Barra do Ribeira, sendo que existem diversos tipos de financiamentos que apóiam iniciativas turísticas de enfoque social e também projetos ligados à conservação ambiental. Estes financiamentos ou até mesmo doações, podem ser oriundos tanto de organizações nacionais, como a Petrobrás, mas também de organismos internacionais. Para isso, devem ser realizados estudos sobre a situação da Barra do Ribeira, seu contexto ambiental e social; assim como um inventário no Bairro para que haja a elaboração de projetos e planejamento adequados para o requerimento de financiamentos.

As condições precárias do local oferecem restrições para alguns tipos de turistas, principalmente àqueles que não possuem condução própria, já que muitos dos atrativos se encontram distantes do centro. Chegar à Barra do Ribeira sem veículo próprio pode representar alguns imprevistos para o turista. Na rodoviária de Iguape saem poucos ônibus para a Barra do Ribeira e um dos trajetos realizados demora cerca de uma hora para chegar até a Balsa devido às más condições da estrada de terra, piorando ainda mais em períodos de chuva. Em feriados prolongados, devido ao trânsito nas estradas o turista corre o risco de perder o ônibus que sai da rodoviária, onde poderia haver vans ou jipes que pudessem realizar viagens até a balsa. A falta de informação sobre os horários dos ônibus também gera desconforto, sendo que nos feriados os horários são alterados e os turistas desconhecem o itinerário do ônibus.

A locomoção na Barra do Ribeira também é difícil, pois da Balsa até onde estão localizados os meios de hospedagem, a distância é longa. Assim seriam necessários meios de transporte que não agridam o meio ambiente, sendo que aqui apresenta-se 
como sugestão a utilização de charretes de bicicleta para conduzir os turistas, onde poderia ser mais uma alternativa de renda para a população. Além disso, com a paralisação das atividades de monitoria ambiental da AMAI, são realizados poucos passeios organizados para as atrações, onde as informações sobre estes passeios são muito vagas.

Surge a partir destas condições identificadas, a necessidade da reabertura do Posto de informações turísticas (PIT), para que os turistas sejam informados sobre os atrativos, além de poderem ser distribuídas cartilhas de cunho educacional sobre a importância da Juréia. Como ação de educação ambiental, poderiam também ser realizadas atividades recreativas na Praia, seguindo o exemplo da Campanha Verão Limpo e a continuação do trabalho da AMAI.

Estas sugestões devem ser realizadas em conjunto com os moradores, os proprietários de residência na Barra do Ribeira, empreendedores locais e também de turistas que se sentiram atraídos pelo local. O potencial turístico da região só será firmado a partir de um consenso e união entre todos os envolvidos, sendo que muitas ações não dependem apenas de políticas públicas, mas sim de um exercício de cidadania e boa vontade de todos.

Este trabalho teve como intuito alertar para a urgência de um planejamento sustentável para o local, de modo a fazer da atividade turística uma estratégia para se alcançar o desenvolvimento sustentável local e a preservação de uma área significativa da Mata Atlântica. 


\section{REFERÊNCIAS BIBLIOGRÁFICAS}

ADAMS, Cristina. As populações caiçaras e o mito do bom selvagem: a necessidade de uma nova abordagem interdisciplinar. Revista Antropol., São Paulo, v. 43, n. 1, 2000. Disponível em: http://www.scielo.br/scielo.php?script=sci arttext\&pid=S0034-

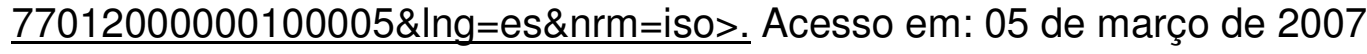

Agência Estado. 09/04/2003. Disponível em: http://www.agenciaestado.com.br. Acesso em: 15 de janeiro de 2007.

Associação Eco Juréia: Disponível em: http://www. ecojureia.com.br. Acesso em: 08 jan 2007.

ASSOCIAÇÃO ECO JURÉIA. Diagnóstico. 2002

AMAI. Dossiê AMAI. 2002

Barra do Ribeira: Município da Juréia?Jornal da Juréia. Ano V, no19, jan-fev-mar 2005

BRASIL. Ministério do Turismo. Segmentação do Turismo. Marcos Conceituais. 2003

BRANDON, K. Etapas básicas para incentivar a participação local em projetos de turismo voltado para a natureza. In: LINDBERG KREG, Hawkins (org). Ecoturismo: um guia para planejamento e gestão. São Paulo: Editora SENAC, 2002. Comissão Mundial sobre Meio Ambiente e Desenvolvimento. Nosso Futuro Comum. 1991

Caiçaras se tornam professores para resgatar tradição de sua comunidade. Disponível em: http://www.ruralnet.com.br/meioambiente/default.asp?noticia=1517. Acesso em 08 de fevereiro de 2007.

Câmara Municipal de Iguape. Disponível em: http://www.camaraiguape.sp.gov.br. Acesso em: 23 de janeiro de 2007.

Campanha Verão Limpo atrai 3,5 mil pessoas em Iguape e Ilha Comprida. Secretaria do Meio Ambiente. Notícias. Disponível em: http://www.ambiente.sp.gov.br/destaque/2007/01/16 verao.htm. Acesso em: 15 de janeiro de 2007.

CD Ecoturismo na Mata Atlântica: Um Guia Interativo sobre o Vale do Ribeira.s.d

Esclarecimentos a Rede CTA-JMA do Instituo Ing-Ong e da AMAl. Disponível em: http://www.ruralnet.com.br/meioambiente/default.asp?noticia=1552. Acesso em: 06 de janeiro de 2007 
Escola da Juréia propõe convivência entre a mata e a comunidade cultural. Disponível em: http:// www.cienciaecultura.bvs.br/pdf/cic/v55n3/a08v55n3.pdf Acesso em: 14 de março de 2007.

Globo Rural: Caixeta. Disponível em: http://globorural.globo.com/barra.asp?d=/edic/173/fichaplanta1.htm. Acesso em: 15 de maio de 2007

Instituto de Economia Agrícola.Disponível em: http://www.iea.org.br. Acesso em: 27 de fevereiro de 2007.

Juréia. Disponível em: www.jureia.org.br. Acesso em: 01 de março de 2007.

KINKER, S. Ecoturismo e conservação da natureza em parque nacionais. Campinas: Editora Papirus, 2002.

LACORTE,G. RIBEIRO, M. Gestão Social do Turismo. Disponível em: http://200.189.169.141/site/br/dados fatos/conteudo/ver.php?in secao=311\&idConteud $\underline{0=29}$. Acesso em: 16 de março de 2007.

LIMA, Ana Claudia. GITA, Ana. Trabalho com populações tradicionais. Melhores Práticas para o Ecoturismo. Manual MPE 2001. Disponível em: http://mpefunbio.org.br Acesso em: 25 de fevereiro de 2007

MAGALHÃES, S. W.G. Pólos Ecoturísticos: planejamento e gestão. São Paulo: TERRAGRAPH, 2001.

MAGALHÃES, N.W. Descubra o Lagamar.São Paulo: ECO - Associação para Estudos do Ambiente, 1998.

Manifesto AMAI. Disponível em:

http://www.ruralnet.com.br/meioambiente/default.asp?noticia=1523. Acesso em 06 de janeiro de 2007.

MONGUE. Disponível em:http://www.mongue.org.br. Acesso em 23 de janeiro de 2007.

Museu Vivo do Fandango. Disponível: http://www.museuvivodofandango.com.br. Acesso em: 04 de janeiro de 2007

NETO, P.N. Breve história da área Juréia-Itatins como unidade de conservação. In: MARQUES, O. A.V \& DULEBA, W. (ed). Estação Ecológica Juréia-Itatins: Ambiente físico, flora e fauna. Ribeirão Preto: Holos, 2004.

NUNES, M. Do passado ao futuro dos moradores tradicionais da estacao ecologica Jureia-Itatins/SP. São Paulo, 2003. 151 p. Dissertação (Mestrado). 
NOLASCO,A. \& VIANA, V. Problemas e oportunidades para a indústria de processamento primário da caixeta. Disponível em: http://www.ipef.br/publicacoes/ctecnica. Acesso em: 11 de maio de 2007.

PONTES, B \& QUEIROZ, O. O (re)arranjo de lguape e Ilha Comprida sob o advento do turismo e da exploração de recursos naturais. In: LEMOS, G. Amália Inês. (Org.). Turismo: Impactos Sócio Ambientais. São Paulo: Hucitec, 1996.

.PT Assembléia Permanente. Disponível em: http://ptalesp.locaweb.com.br/CN02/desmonte/nots det.asp?id=347. Acesso em: 12 de janeiro de 2007.

Revista Turismo, junho/2004. Disponível em: http://www.revistaturismo.com.br/. Acesso em: 18 de fevereiro de 2007.

ROMAO, D.ECOTURISMO: diagnóstico, potencial e possibilidades de ação no Vale do Ribeira, Estado de São Paulo. 1998. Informações Econômicas. São Paulo. V.33, n 6. 2003.

RUSCHMANN, D. Turismo e planejamento sustentável: a proteção ambiental. São Paulo: Editora Papirus, 1997.

Superintendência do Desenvolvimento do Litoral Paulista - SUDELPA. Plano básico de desenvolvimento auto-sustentado para a região lagunar de Iguape- Cananéia. São Paulo, 1987.

SÃO PAULO (Estado). Secretaria do Meio Ambiente. Coordenadoria de Educação Ambiental. Diretrizes para uma política estadual de ecoturismo. São Paulo, 1997

São Paulo.Secretaria do Meio Ambiente. PROJETO DE DESENVOLVIMENTO DO ECOTURISMO NA REGIÃO DA MATA ATLÂNTICA. Estudo Ambiental. 2005

Secretaria do Estado do Meio Ambiente: Regulamentação da APA Cananéia -IguapePeruíbe: Plano de gestão/ ZEE. SÂO PAULO: SMA: IBAMA, 1996

SOS MATA ATLÂNTICA. Pólo Ecoturístico do Lagamar um Estudo de Caso. São Paulo: Fundação SOS Mata Atlântica. 2004

SOS Mata Atlântica. Disponível em: http:// www.sosribeira.org.br. Acesso em: 17 de fevereiro de 2007.

SWARBROOKE, John. Turismo Sustentável: conceitos e impacto ambiental. São Paulo: Aleph, 2000. 
